\section{OPEN ACCESS}

Edited by:

Jun Lu,

Auckland University of Technology,

New Zealand

Reviewed by:

Jiuhong Zhang,

Southeastern Oklahoma State

University, United States

Zois Syrgiannis,

Northwestern University, United States

Enyi Ye,

Institute of Materials Research and

Engineering ( $A^{*}$ STAR), Singapore

${ }^{*}$ Correspondence:

Dai-Xu Wei

weidaixu@nwu.edu.cn

Guohua Xu

xuguohuamail@smmu.edu.cn

Jiangming $Y_{U}$

yjm_st@163.com

${ }^{\dagger}$ These authors have contributed equally to this work

Specialty section

This article was submitted to Nutrition and Food Science

Technology

a section of the journal

Frontiers in Nutrition

Received: 29 April 2021

Accepted: 08 July 2021

Published: 24 August 2021

Citation:

Xu N, Peng X-L, Li H-R, LiU J-X,

Cheng J-S-Y, Qi X-Y, Ye S-J,

Gong $H$-L, Zhao $X-H, Y u$ J, Xu G and

Wei D-X (2021) Marine-Derived

Collagen as Biomaterials for Human

Health. Front. Nutr. 8:702108.

doi: 10.3389/fnut.2021.702108

\title{
Marine-Derived Collagen as Biomaterials for Human Health
}

\begin{abstract}
Ning X ${ }^{1+}$, Xue-Liang Peng ${ }^{2 t}$, Hao-Ru Li ${ }^{2 t}$, Jia-Xuan Liu ${ }^{2}$, Ji-Si-Yu Cheng ${ }^{2}$, Xin-Ya Qi ${ }^{2}$, Shao-Jie Ye ${ }^{2}$, Hai-Lun Gong ${ }^{2}$, Xiao-Hong Zhao ${ }^{2}$, Jiangming $\mathrm{Yu}^{3 *}$, Guohua $\mathrm{Xu}^{1 *}$ and $\mathrm{Dai}-\mathrm{Xu} \mathrm{Wei}^{2 *}$
\end{abstract}

${ }^{1}$ Department of Orthopedics, Second Affiliated Hospital, Naval Medical University, Shanghai, China, ${ }^{2}$ Key Laboratory of Resource Biology and Biotechnology in Western China, Department of Life Sciences and Medicine, Ministry of Education, School of Medicine, Northwest University, Xi'an, China, ${ }^{3}$ Department of Orthopedics, Tongren Hospital, Shanghai Jiaotong University, Shanghai, China

Collagen is a kind of biocompatible protein material, which is widely used in medical tissue engineering, drug delivery, cosmetics, food and other fields. Because of its wide source, low extraction cost and good physical and chemical properties, it has attracted the attention of many researchers in recent years. However, the application of collagen derived from terrestrial organisms is limited due to the existence of diseases, religious beliefs and other problems. Therefore, exploring a wider range of sources of collagen has become one of the main topics for researchers. Marine-derived collagen (MDC) stands out because it comes from a variety of sources and avoids issues such as religion. On the one hand, this paper summarized the sources, extraction methods and characteristics of MDC, and on the other hand, it summarized the application of MDC in the above fields. And on the basis of the review, we found that MDC can not only be extracted from marine organisms, but also from the wastes of some marine organisms, such as fish scales. This makes further use of seafood resources and increases the application prospect of MDC.

\footnotetext{
Keywords: marine-derived collagen, tissue engineering, drug delivery system, cosmetics, food, health care product
}

\section{INTRODUCTION}

Collagen is a kind of biological macromolecule, which is the richest protein in the human body, accounting for more than $30 \%$ of the total body protein (1). It is the main material of extracellular matrix of skin, bone, ligament, cartilage and tendon. More than $85 \%$ of human collagen is type I, while other common types of collagens include type II, III, and IV. Collagen is a trimer composed of three polypeptide $\alpha$ chains (2). And it has a typical triple helix structure and glycine, proline and hydroxyproline residues is rich.

Collagen as a biomaterial is widely used in various fields due to its biocompatibility, biodegradability, accessibility and high throughput $(3,4)$. However, the health of collagen extracted from cattle and pigs is very worrying due to diseases (5). For example, outbreaks of bovine spongiform encephalopathy (BSE), infectious spongiform encephalopathy (TSE) and foot-andmouth disease (FMD) have aroused wide health concerns about the use of collagen and collagen derived products in terrestrial animals (6). In addition, religious disputes are inevitable (7). At present, collagen has been extracted from many marine products. Marine-derived collagen (MDC) solves the problems of other animal diseases and pathogens. And, MDC has better chemical and physical durability and is abundant in quantity $(8,9)$. 
In recent years, MDC in various fields has been widely used due to its extensive sources, simple extraction methods, good biocompatibility, edibility and so on. This paper summarizes the sources, extraction methods and characteristics of MDC. In addition, the application of MDC in medical tissue engineering, drug delivery, cosmetics, food and other fields was reviewed. On this basis, we preliminarily explored the biocompatibility of gill dolphin collagen and tilapia collagen as well as the application in skin tissue engineering.

Many researchers have been looking for alternative sources of collagen in aquatic animals $(10,11)$. With the extraction of MDC, fish skin, fish scale and other fishery wastes have been better utilized. Transforming waste into collagen solves the environmental problems related to fish $(12,13)$. The use of collagen derived from terrestrial animals is controversial due to the problems related to disease, religion and so on. However, as a biomaterial with a wide range of sources, MDC has attracted more and more researchers because of its good biocompatibility and degradation properties.

\section{SOURCE, EXTRACTION, AND CHARACTERIZATION}

With the increasing demand for collagen, new materials are needed as the source of collagen (Tables 1, 2). Extracting collagen from marine organisms can not only avoid the problem of religious belief, but also has its unique properties. The efficiency and effectiveness of collagen extraction process has always been considered in the process of collagen extraction. Compared with the conventional acid assisted and pepsin assisted extraction of collagen, the collagen extracted by the improved physical assisted process retains a higher molecular weight, and the peptide spectrum is similar to that extracted only with acid (88). In addition, collagen extracted from dried jellyfish and squid has potential applications in biomedicine, medicine and health care products (89). As shown in Table 3, methods of extracting MDC are reported.

Electrodialysis is also a promising technology, but it has not been applied to the extraction of fish collagen. At present,

TABLE 1 | Characterization and amino acid characteristics of MDC.

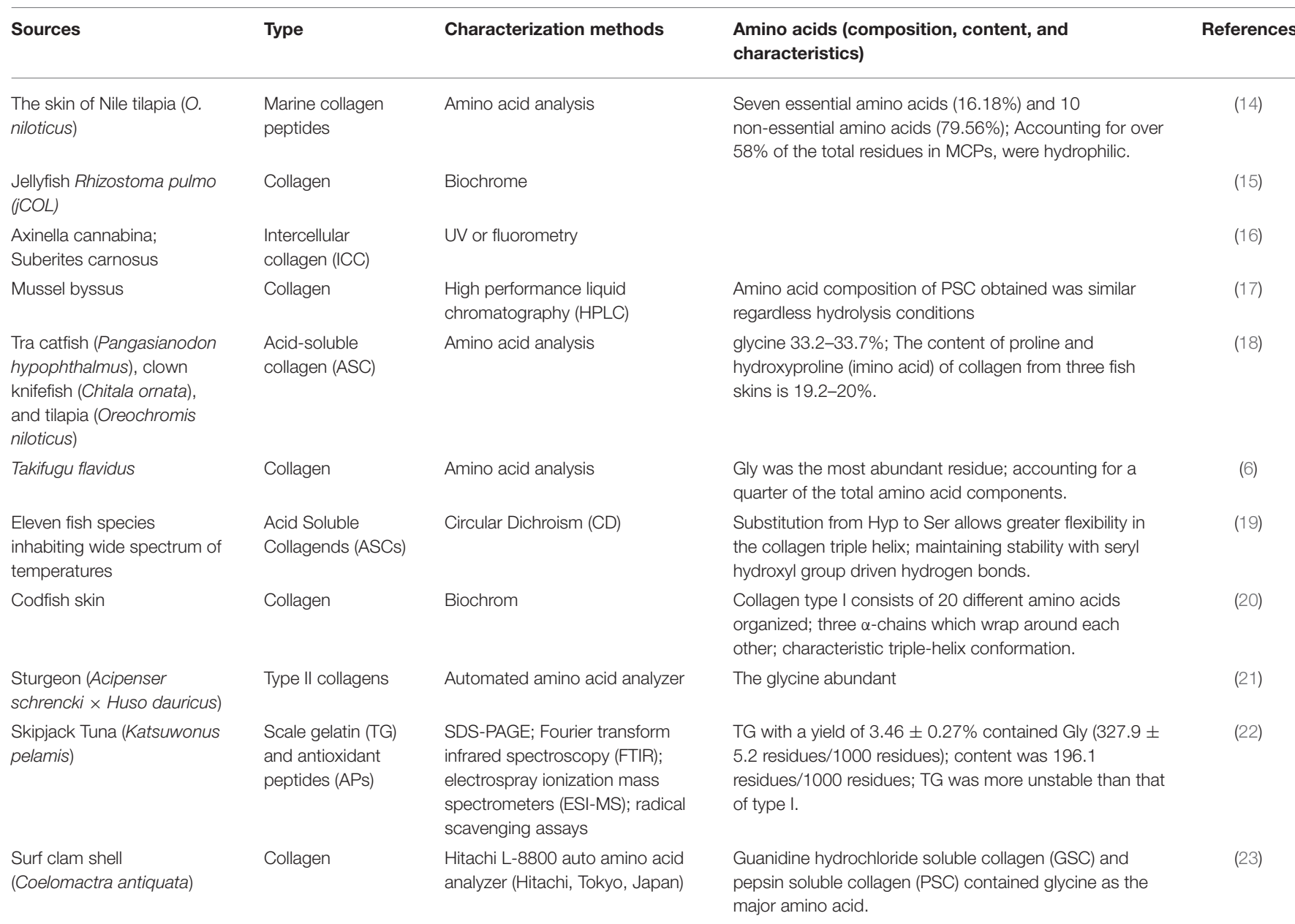


TABLE 2 | Sources of various marine-derived collagen (MDC).

\begin{tabular}{|c|c|c|}
\hline Species & Tissue or organs & References \\
\hline \multirow[t]{3}{*}{ Tilapia } & Skin & $(14,24-27)$ \\
\hline & Scale & $(28-35)$ \\
\hline & Unknown & $(36-39)$ \\
\hline Jellyfish & Unknown & $(40-47)$ \\
\hline \multirow[t]{2}{*}{ Shark } & Skin & $(48-51)$ \\
\hline & Cartilage & $(52)$ \\
\hline \multirow[t]{3}{*}{ Salmon } & Skin & $(53-59)$ \\
\hline & Bone & (60) \\
\hline & Scale & (60) \\
\hline Sponge & Unknown & $(27,61-66)$ \\
\hline \multirow[t]{2}{*}{ Snakehead fish } & Scale & $(67)$ \\
\hline & Unknown & (68) \\
\hline \multirow[t]{2}{*}{ Tuna } & Skin & (69) \\
\hline & Unknown & (70) \\
\hline \multicolumn{3}{|l|}{ Others: Prionace } \\
\hline glauca & Skin & $(71)$ \\
\hline $\begin{array}{l}\text { Giant croaker (Nibea } \\
\text { japonica) }\end{array}$ & Swim bladder & (72) \\
\hline Sole fish & Skin & (73) \\
\hline Codfish & Skin \& bone & (74) \\
\hline Sparidae & / & (75) \\
\hline Sturgeon fish & / & (76) \\
\hline Gadiformes & Skin & $(77)$ \\
\hline Mrigal fish & Scale & (78) \\
\hline Flatfish & Skin & (79) \\
\hline Weever & Skin & (80) \\
\hline Seabass & Scale & (81) \\
\hline Silver carp & Skin & (82) \\
\hline Synodontidae fish & Scale & (83) \\
\hline Eel & Skin & (84) \\
\hline Codfish & / & (20) \\
\hline Gadus morhua & / & (85) \\
\hline Cyprinus Carpio & / & (86) \\
\hline Grouper & Swim bladder & (87) \\
\hline
\end{tabular}

the physical and chemical properties of flavonoid collagen are retained by electrodialysis, which fully shows its advantages in the experiment. Therefore, we can assume that electrodialysis can also improve the production environment of fish collagen (95). The extraction of collagen from fish skin improves the value of marine by-products and avoids the pollution caused by large amounts of waste. Taking Atlantic cod as an example, the extraction rates of collagen by acetic acid and pepsin were 5.72 and $11.14 \%$, respectively (96). Compared with the traditional organic acid solution extraction, the extraction rate of collagen and the properties of products are improved by $\mathrm{CO}_{2}$ acidification water, which has potential value in the field of biomedicine and cosmetics (97).

Marine resources have great potential (Figure 1). When looking for natural moisturizing cosmetics, sea cucumber is finally selected. Pepsin soluble collagen was extracted from sea cucumber wall. Its moisture retention and moisture absorption with tilapia collagen are better than those of glycerol, which shows the potential application of MDC in cosmetics (98) (Table 4).

All of the fish collagen extracts were found to have high levels of imino acids (227-232/1000 residues). All collagen is soluble at acidic $\mathrm{pH}$. In addition, the high collagen content, especially in the skin, and the good thermal properties [thermal transition temperature $\left(31.6-33.7^{\circ} \mathrm{C}\right)$ and thermal denaturation temperature $\left.\left(31.1-32.2^{\circ} \mathrm{C}\right)\right]$ of the extracted collagen suggest that they have great potential as a collagen substitute in mammals (70). The low denaturation temperature of sponge collagen enables gelatin extraction at a lower temperature than that of mammalian gelatin. MDC is considered to be an equivalent biomaterial that is safer than the land-based biomaterials that currently dominate the market. The results showed that sponges A. cannabina and S. carnosus could be used as substitutes for collagen. If marine sponge is used as gelatin raw material in the food industry, it will bring high economic benefit (16). MDC also has promising applications in vitro 3D bioprinted models. But not the product of the modification of collagen and collagen denaturation gelatin easy rapid degradation. In order to solve this problem, in past research, scientists have developed a collagen and gelatin crosslinking of the chemical and physical methods, increasing the tunability of their mechanical properties. Marine collagen can be used as a biomaterial for tissue engineering and $3 \mathrm{D}$ bio-printing by controlling the content of methacrylate, as well as the intensity duration of ultraviolet light and the concentration of photoinitiator to control the required degree of cross-linking (122). The hydrogel with rheological characteristics was prepared by combining high-yield collagen with chondroitin sulfate. In addition, prionace glauca (PG) pepsin-soluble collagen (PSC) combined with shark-derived chondroitin sulfate produces a hydrogel with a cohesive polymer matrix that can be used for cartilage regeneration (91). The results showed that the best collagen yield was obtained when the papain concentration was $7,000 \mathrm{U} / \mathrm{mg}$, and the $\mathrm{pH}$ value was $5.90,22.79 \%$ collagen was hydrolyzed with alcalase and then separated by gel filtration chromatography. Compared with unhydrolyzed collagen, the four major components of the hydrolyzed product showed significant antioxidant and antiglycosylation activity (123). Based on previous studies, we summarized some characterization methods of MDC, aiming to understand the characteristics of the components of MDC (Table 1).

\section{IN MEDICAL TISSUE ENGINEERING}

Tissue engineering and regenerative medicine is an emerging and rapidly growing life sciences domain. Using engineering and biological theory to create biomimetic tissues and organs on the basis of biological materials has become a common idea and hot topic among scientists in recent years. The excellent biocompatibility of MDC has stimulated its potential role in the design of biomaterial scaffolds in tissue engineering and regenerative medicine (Figure 2; Table 4). 
TABLE 3 | Extraction methods of MDC and their advantages and disadvantages.

\begin{tabular}{|c|c|c|}
\hline Sources & Extraction method & Principle \\
\hline Mussel byssus & Pepsin solutions & $\begin{array}{l}\text { Pepsin is typically indiscriminate in its digestion } \\
\text { of proteins, with the notable exception of the } \\
\text { triple helical domain of native collagen with } \\
\text { further limited pepsin digestion, the } \\
\text { cross-linked molecules at the telopeptide } \\
\text { region are cleaved without damaging the } \\
\text { integrity of the triple helix. }\end{array}$ \\
\hline $\begin{array}{l}\text { Axinella cannabina; } \\
\text { Suberites carnosus }\end{array}$ & $\begin{array}{l}\text { Alkaline solubilization, } \\
\text { trypsin solubilization }\end{array}$ & $\begin{array}{l}\text { The first method was initially introduced for the } \\
\text { isolation of insoluble collagen (InSC) from G. } \\
\text { cydonium and C.reniformis by employing an } \\
\text { alkaline, both denaturing and reducing, } \\
\text { homogenization buffer affording collagen in } \\
\text { high yield; } \\
\text { The second one utilizes a trypsin-containing } \\
\text { extraction buffer, known to destroy the } \\
\text { interfibrillar matrix and, therefore, releasing the } \\
\text { collagen fibrils (ICC). After exhaustive water } \\
\text { extraction, the remaining debris generally } \\
\text { comprises the spongin/spongin-like collagen. }\end{array}$ \\
\hline
\end{tabular}

Surf clam shell
(Coelomactra antiquata)
Indian major carp rohu
(Labeo rohita)
Bigeye tuna
Shark (Prionace glauca) and
ray (Zeachara chilensis and
Bathyraja brachyurops)
Codfish skin

Salmon Byproducts

Nile tilapia (Oreochromis niloticus) skin

Jellyfish (Acromitus hardenbergi)

Takifugu flavidus
Guanidine

hydrochloride and

pepsin

Enzymatic method

Acetic acid and pepsin

Acidic and enzymatic

extractions

An acid-base

procedure

Bacterial extracellular proteases fermentation

Collagen extraction

after fermentation

pretreatment

Physical-aided

acid-assisted

extraction method

Electrodialysis extraction
Increase physical intervention.

This method can purify charged proteins/peptides by ion-exchange membranes through a stimulated diffusion process under the influence of electric potential difference.
Advantages

- Ensure the integrity of the collagen

molecule
Disadvantages

References

- Reagent residues in collagen;

- Generate

abundant

waste liquid;

- Resulting in environmental pollution
- Safer;

- Cheape;

- More moderate;

- Less destructive than acid hydrolysis

Potential bioactive released;

- The reaction time

is shortened.

- Type I collagen with high purity;

- Retained the integrity

of their triple

helical structure.

- Similar amino acids composition;

- Retained high molecular weight distributions;

- High efficiency;

- Large capacity;

- High extraction yield;

- Better

environmental sustainability

electrospinning

processes

\section{Bone Tissue Engineering}

MDC with its high hydrophilicity and amino acids provides the optimal extracellular microenvironment and has many applications in bone tissue. It can promote the proliferation and differentiation of osteoblasts, and the bone marrow mesenchymal stem cells (BMSCs) that induce osteoblastic differentiation retain their immunomodulatory function. For example, tilapia collagen can promote the growth and differentiation of osteoblasts without the use of any additional induction reagents $(28,49)$, just as human bone marrow mesenchymal stem cells (hMSCs) 


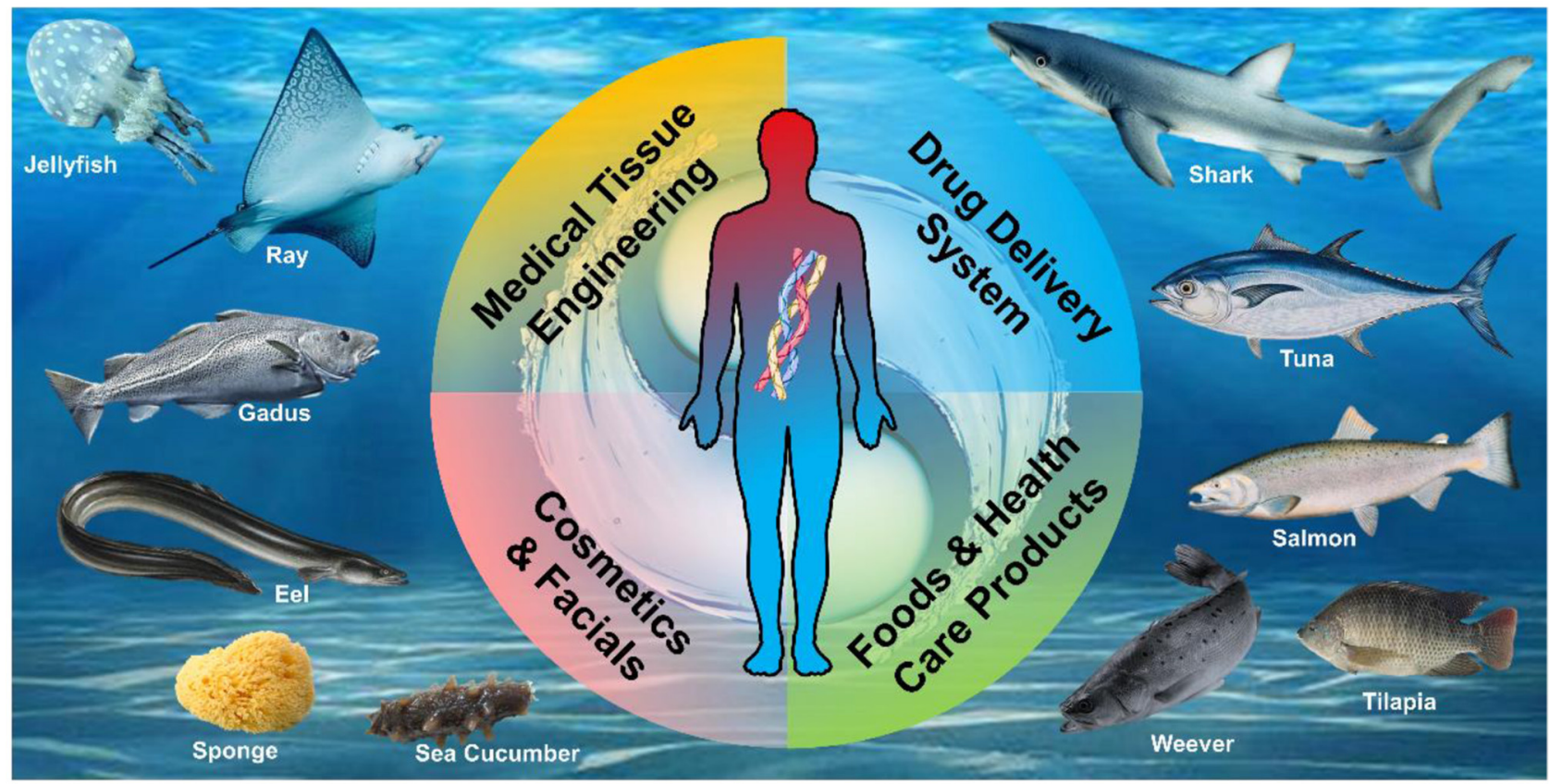

FIGURE 1 | Abundant marine-derived collagen (MDC) as biomaterials are extracted from various marine organisms for human health.

readily adhere to tilapia squamous collagen during cell culture in vitro, thus significantly accelerating the early differentiation of hMSCs into osteoblasts (75). Biphase scaffolds of biomimetic mineralized salmon collagen and fibrotic jellyfish collagen were prepared by combining lyophilized and cross-linked methods, indicating that they can support chondroblast and osteogenic differentiation of hMSCs in vitro (41). Shark skin collagen also promotes the growth of osteoblasts and the synthesis of collagen in bone cells (49). When this collagen was further mixed with calcium phosphate from shark teeth to form a 3D composite scaffold, it could support the attachment and proliferation of osteoblast-like cells (48). Some researchers also found that the collagen peptide extracted from the scales of two kinds of fish, Sephareidae, can promote the proliferation of osteoblasts and inhibit the proliferation of mature osteoclasts, which can be used to prevent osteoporosis and help bone remodeling (50). In Codfish, low concentration of fish collagen peptide (FCP) may promote the proliferation of cells, and also promote the expression and differentiation of apoptotic osteoblasts (74). Collagen in salmon skin can also significantly up-regulate gene expression of various collagen-modifying enzymes in mouse preosteoblastic cells (MC3T3-E1) osteoblasts, which has a positive effect on osteoblasts (59).

MDC can also play a great role in bone development and bone injury repair. They used a sponge-collagen-based (SPG) scaffold and photobiodularization (PBM) to test a model of skull defect in Wistar rats. The results showed that SPG/PBM treated rats showed more connective tissue and newly formed bone tissue in the defect area (66). Mixing sponge collagen with hydroxyapatite (HA) to form scaffolds has the potential to improve graft performance for bone regeneration applications (62). MDC peptide (MCP) extracted from salmon skin was used to study the femur of growing rats. The results showed that MCP supplementation could increase the femur volume, bone density, dry weight and ash content of growing male rats. Therefore, $\mathrm{MCP}$ supplementation could promote the development of long bone in growing male rats (104): The effects of MDC oligopeptides and calcium aspartate on bone mineral density in ovariectomized Wistar rats were studied. It was found that the combination of MDC oligopeptides and calcium aspartate could significantly improve bone mineral density, which also indicated that MDC oligopeptides could promote the absorption of calcium aspartate (103). All these indicate that MDC has a good effect on bone growth and development.

In future studies, MDC may also provide new options for bone grafting and regeneration. Researchers have successfully developed a novel collagen fiber wikestone hydrogel based on the dual network (DN) concept using fish swim bladder collagen (SBC) extracted from sturgeon. The gel was implanted into the osteochondral defect of rabbit knee joint and showed good biomechanical properties in vivo. Mixed with hydroxyapatite wrapped DN gel combined with bone also is good. This kind of new collagen matrix composite DN gel has good biomechanical properties and combined with bone, is a kind of soft, elastic ceramic material, to design the next generation of orthopedic implants as artificial cartilage, the body weight bearing area of bone defect repair material provides a new choice (76). For bone regeneration, low immunogenicity fish collagen protein and bioactive nano-hydroxyapatite (N-HA)-reinforced polylactide glycogen (PLGA) nanofiber membranes were prepared for 
TABLE 4 | Applications of MDC in medical tissue engineering.

\begin{tabular}{|c|c|c|c|c|c|}
\hline Applications & Manufacture technique & Forms & Additive materials & Biological evaluation & References \\
\hline \multirow{20}{*}{$\begin{array}{l}\text { Bone } \\
\text { Tissue } \\
\text { Engineering }\end{array}$} & / & Scaffolds & Hydroxylapatite & / & (99) \\
\hline & / & Scaffolds & Hydroxylapatite & / & $(100)$ \\
\hline & $\begin{array}{l}\text { Freeze-drying and EDC } \\
\text { cross-linked }\end{array}$ & Scaffolds & Alginate & hMSCS & $(41)$ \\
\hline & / & Solution & Moringa oleifera & Albino rats & $(101)$ \\
\hline & $\begin{array}{l}\text { Freeze- } \\
\text { drying/dehydrothermal } \\
\text { treatment }\end{array}$ & Scaffolds & Glycosaminoglycan & MC3T3-E1 & $(48)$ \\
\hline & / & Solution & / & Mouse & (49) \\
\hline & Hydrolysis & Solution & / & BMSCs & $(102)$ \\
\hline & / & solution & / & Human osteoblasts & $(74)$ \\
\hline & / & Scaffolds & / & Wistar rats & (66) \\
\hline & / & Peptide solution & Calcium aspartate & Rats & $(103)$ \\
\hline & Freeze-drying & Native collagen & / & Primary hMSCs & (28) \\
\hline & Enzymatical hydrolysis & Peptide & / & Rats & (51) \\
\hline & Enzymatical hydrolysis & Peptide & / & MG-63 cells & $(75)$ \\
\hline & $\begin{array}{l}\text { Freeze-drying/EDC } \\
\text { cross-linked }\end{array}$ & Scaffolds & / & NIH3T3, MG-63 cells and Mouse & $(104)$ \\
\hline & $\begin{array}{l}\text { Freeze-drying/EDC/NHS or } \\
\text { HMDI cross-linked }\end{array}$ & Scaffolds & / & Saos-2 cells & $(50)$ \\
\hline & Freeze-drying & Scaffolds & Chitosan/Hydroxyapatite & MG-63 cells & $(61)$ \\
\hline & $\begin{array}{l}\text { Freeze- } \\
\text { drying/Glutaraldehyde } \\
\text { cross-linked }\end{array}$ & Scaffolds & Chitosan/Hydroxyappatite & 6T-CEM cells & (52) \\
\hline & Vacuum drying & Scaffolds & Hydroxyapatite/PMMA & MC3T3-E1 cells and L929 cells & (62) \\
\hline & Glutaraldehyde cross-linked & Scaffolds & $\begin{array}{l}\text { Poly (N, } \\
\text { N'-dimethylacrylamide) }\end{array}$ & Rabbit bone defect model & $(76)$ \\
\hline & Electrospinning & Scaffolds & PLGA/Hydroxyapatite & $\begin{array}{l}\text { Primary BMSC and Human } \\
\text { gingiva fibroblasts }\end{array}$ & (6) \\
\hline \multirow[t]{13}{*}{$\begin{array}{l}\text { Cartilage tissue } \\
\text { engineering }\end{array}$} & $\begin{array}{l}\text { Freeze-drying/Chemical } \\
\text { cross-linking. }\end{array}$ & Scaffolds & / & hMSCs & (105) \\
\hline & Freeze-drying & Scaffolds & l & Rabbit & $(106)$ \\
\hline & Freeze-drying & Collagen solution & / & hMSCs & $(42)$ \\
\hline & Freeze-drying & Scaffolds & / & $\begin{array}{l}\text { Rabbit chondrocytes and Rude } \\
\text { mice }\end{array}$ & $(107)$ \\
\hline & Cryogelation & Scaffolds & / & & $(71)$ \\
\hline & Freeze-drying & Peptide solution & / & & (91) \\
\hline & Enzymatical hydrolysis & Peptide & / & $\begin{array}{l}\text { Primary horse adipose-derived } \\
\text { stromal cells }\end{array}$ & $(108)$ \\
\hline & Enzymatical hydrolysis & Peptide & / & Rabbit osteoarthritis model & $(77)$ \\
\hline & Acid soluble & Native collagen & / & hMSCs & (29) \\
\hline & $\begin{array}{l}\text { Freeze-drying/EDC } \\
\text { cross-linked }\end{array}$ & Scaffolds & / & $\begin{array}{l}\text { Primary human and rat nasal } \\
\text { septum chondrocytes and Rat } \\
\text { septal cartilage defect model }\end{array}$ & $(45)$ \\
\hline & $\begin{array}{l}\text { Freeze-drying/EDC } \\
\text { cross-linked }\end{array}$ & Scaffolds & Alginate & hMSCs & $(47)$ \\
\hline & Enzymatical hydrolysis & Peptide & / & Human (clinic) & (109) \\
\hline & / & Scaffolds & / & Rats & $(45)$ \\
\hline \multirow[t]{3}{*}{$\begin{array}{l}\text { Dental tissue } \\
\text { engineering }\end{array}$} & Enzymatical hydrolysis & Peptide & l & $\begin{array}{l}\text { Rat odontoblast-like cells } \\
\text { (MDPC-23) }\end{array}$ & (30) \\
\hline & Enzymatical hydrolysis & Peptide & / & $\begin{array}{l}\text { Primary human periodontal } \\
\text { ligament cells }\end{array}$ & (31) \\
\hline & Elecrospinning & Scaffolds & Bioactive glass/Chitosan & $\begin{array}{l}\text { Primary human periodontal } \\
\text { ligament cells and dog furcation } \\
\text { defect model }\end{array}$ & (38) \\
\hline \multirow[t]{2}{*}{ Nerve regeneration } & Enzymatical hydrolysis & Peptide solution & / & Rats & (53) \\
\hline & Acid dissolution & tilapia collagen gel & / & hiPSCs & (37) \\
\hline $\begin{array}{l}\text { Skin tissue } \\
\text { engineering }\end{array}$ & Enzymatical hydrolysis & Peptide solution & / & Rabbit & $(14)$ \\
\hline
\end{tabular}


TABLE 4 | Continued

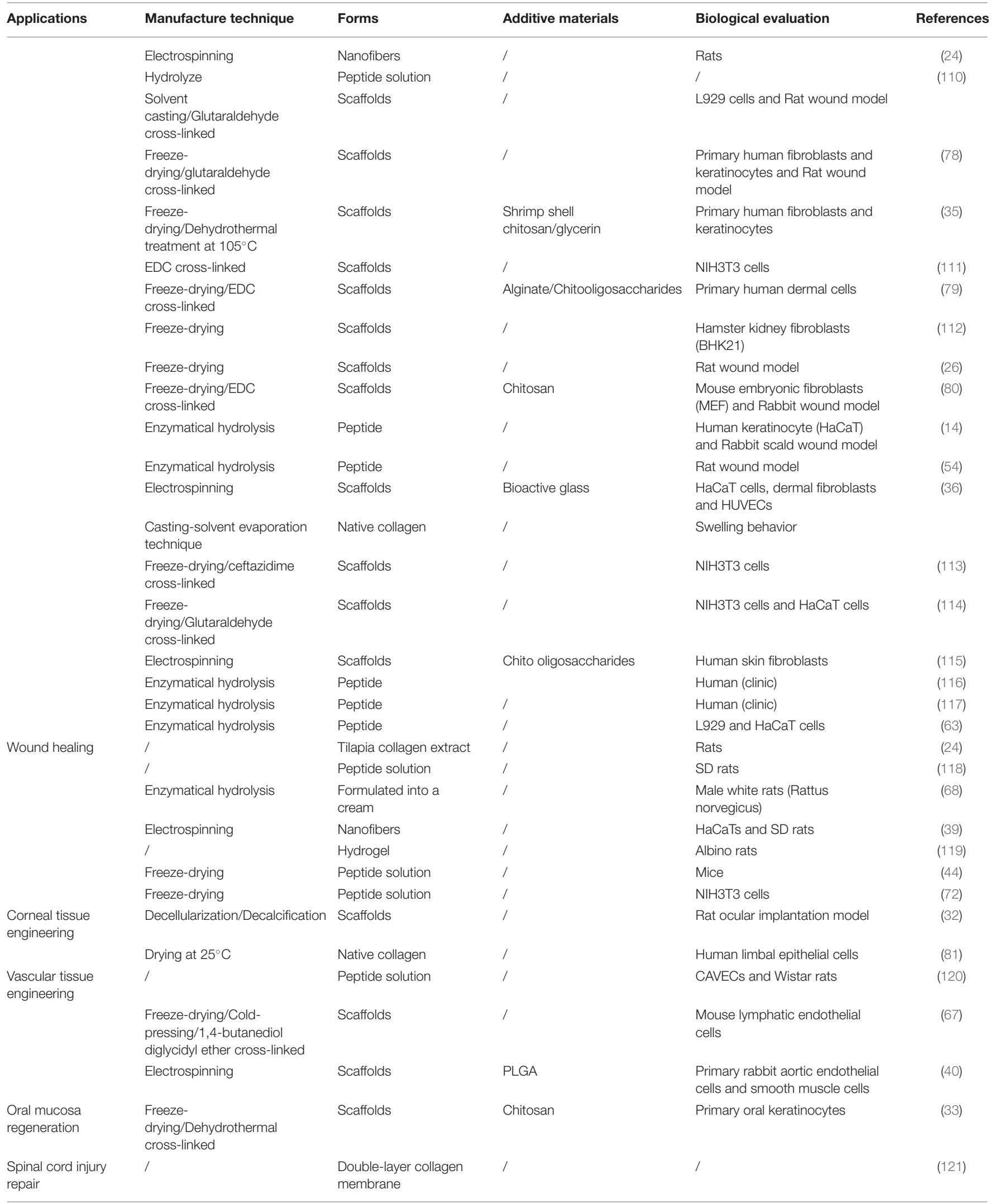

hiPSCs, human induced pluripotent stem cells; hMSCs, human marrow stromal cells; BMSC, bone marrow stromal cells; HUVECs, human umbilical vein endothelial cells; CAVECs, carotid artery vascular endothelial cells. 


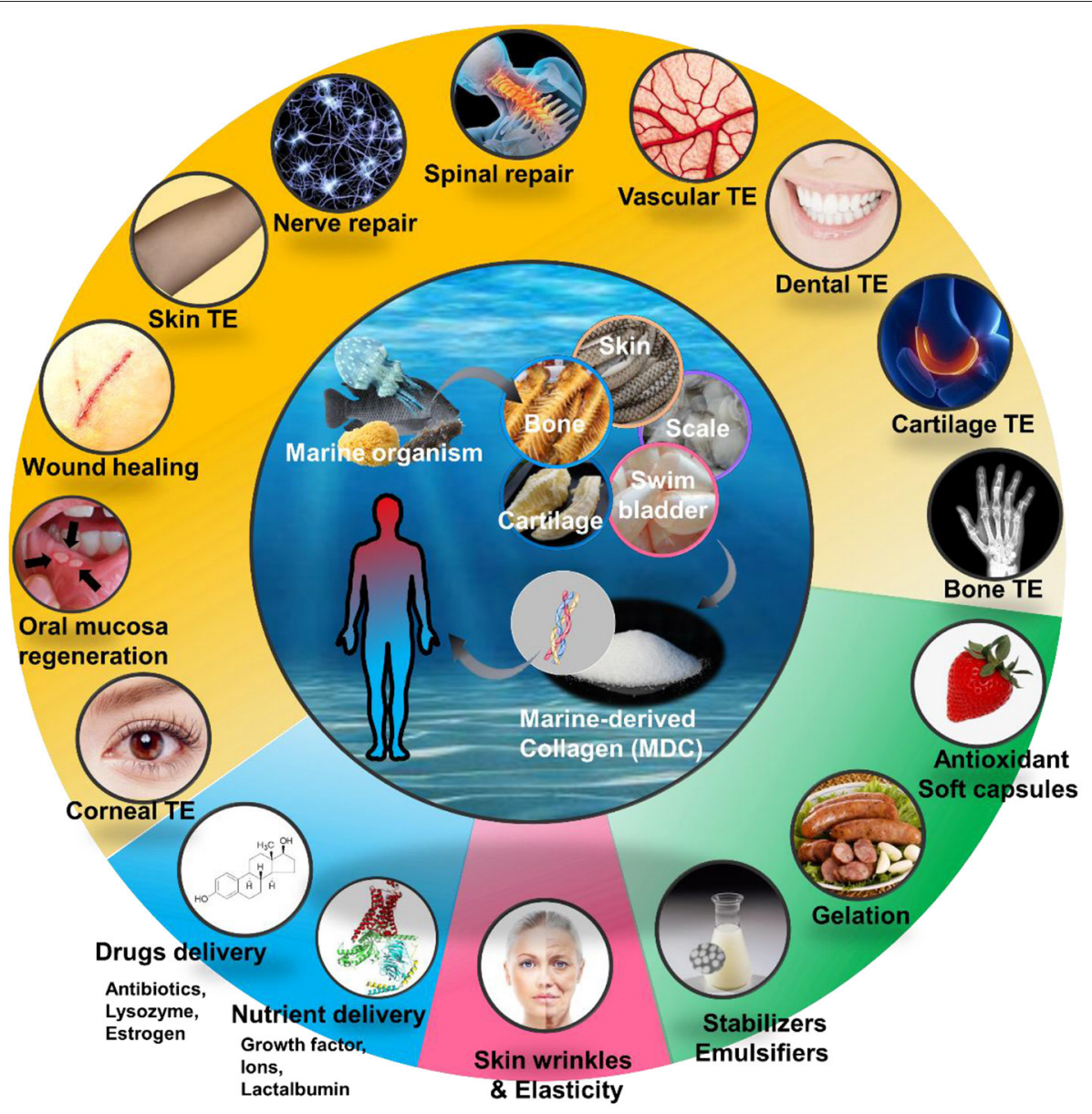

FIGURE 2 | Applications of marine-derived collagen (MDC) for various area in human health, mainly including medical tissue engineering (TE), drug delivery system, cosmetics and Facials, and foods and health care products.

electrospinning guided bone regeneration (GBR). It was found that the membrane had good cytocompatibility with bone marrow mesenchymal stem cells (BMSCs) and human gingival fibroblasts (HGF). The experimental results showed that the composite fibrous membrane has great potential to guide bone or tissue regeneration (6).

\section{Cartilage Tissue Engineering}

MDC plays a very important role in cartilage tissue and enhances chondroblast differentiation. For example, the researchers experimented with chondrogenic differentiation of human bone marrow mesenchymal stem cells (hMSCs) on the collagen fibers of tilapia scales and compared them with porcine collagen and uncoated culture dishes. The results showed that tilapia collagen fibrils in chondrogenic medium specifically enhanced chondrogenic differentiation of HMSCs. Therefore, collagen from tilapia scales can provide a suitable source of collagen for chondrogenic formation of hMSCs in vitro (29). Jellyfish collagen can also be used as a novel cartilage repair implant, using active growth factor nanoreservoir (TGF- $\beta 3$ ), adult human mesenchymal stem cells derived from bone marrow. It was found that jellyfish type collagen implants led to chondrogenic differentiation of mesenchymal stem cells, and TGF- $\beta 3$ as a nanoreservoir led to chondrogenic gene expression and chondrogenic differentiation (42). Using jellyfish collagen as a scaffold, for example, the researchers developed a threedimensional porous scaffold with interconnected pores that can support and maintain chondrogenic differentiation of human mesenchymal stem cells (105). Porous scaffolds of jellyfish collagen fibers and sodium alginate hydrogels are also available (47). And it can stimulate the differentiation capacity of some other cells. For example, the researchers used the blue shark skin collagen with and without external stimuli induced human fat stem cells (hASC) their potential to differentiate into cartilage cells (71), and the sharks and rays of collagen combined shark chondroitin sulfate can be used to simulate human cartilage extracellular matrix. That suggests the MDC, a biomaterial, can be used as a template for cartilage regeneration (91). MDC stimulated the differentiation of chondroblasts and further promoted the formation of cartilage. The researchers prepared a three-dimensional porous fish collagen (FC) scaffold using MDC by freeze-drying technique. When rabbit auricle chondrocytes 
were implanted into porous fish collagen, it was found that it promoted the formation of chondrospecific extracellular matrix (ECM) in vivo and in vitro, and thus promoted the formation of cartilage under the rabbit skin $(106,107)$. TGF- $\beta 1$ can induce chondrogenesis of adipocyte stromal cells (ADSCs) by adding fish collagen to TGF- $\beta 1$, which can induce chondrogenesis effectively (108).

In cartilage tissue repair, the MDC matrix provides excellent performance for cartilage tissue engineering through the experiments of nasal cartilage repair with MDC in situ model of rats (45). It also has a protective effect on cartilage (77).

\section{Dental Tissue Engineering}

In previous research, some researchers used type I collagen from tilapia scales in rat experiments to show that it has similar biocompatibility with pig skin collagen, which reminds us that tilapia scales collagen has the potential to replace mammalian type II collagen in oral and maxillofacial tissue regeneration. Soon after, the researchers carried out the periodontal membrane cell culture experiment of hydrolyzed tilapia collagen and proved that it had the function of periodontal tissue regeneration in vitro. The collagen of tilapia was extracted by electrospinning method, and the composite nanofiber membrane was prepared with bioactive glass and chitosan. The cell viability and osteogenic gene expression of human periodontal ligament cells (HPDLCs) were detected by the composite membrane in the canine class II bifection defect model experiment. It also promoted the expression of Runt-related transcription factor 2 (RUNX-2) and osteopontin (OPN) proteins $(30,31,38)$. In conclusion, the application of MDC in teeth also has great potential.

\section{Vascular Tissue Engineering}

MDC also has some applications in vascular tissue. For example, MDC can promote the growth of vascular endothelial cells. Experimental studies have investigated the protective effect of MDC peptides (MCPs) on carotid vascular endothelial cells (CAVECs) in type 2 diabetes mellitus (T2DM) and its mechanism. They injected Wistar rats with different concentrations of MCPs. In vitro, the vascular/endothelial construction of human umbilical vein endothelial cells (HUVECs) was cultured. Then, inflammatory exudation and related molecular markers of the vena cava endothelial cells were detected and analyzed. The results showed that MCP treatment for 4 weeks significantly reduced blood glucose, endothelial thinning. And inflammatory exudation of carotid vascular endothelial cells was reduced in rats. In vitro, high glucose intervention increased apoptosis in HUVECs significantly. Moderate and high doses of MCPs partially improved this high glucose mediated apoptosis and reduced the level of apoptotic biomarkers. Therefore, moderate dose of MCP inhibits apoptosis and reduces the expression of coupling factor 6 and microparticles, suggesting that we can use MCP to prevent early cardiovascular complications of T2DM (120). Some researchers also used freeze-drying and electrospinning to prepare MDC and PLGA fiber tubular scaffolds for vascular transplantation, and the electrospinning fiber PLGA layer on the surface of porous tubular collagen scaffolds in dry and wet states improved the mechanical strength of collagen scaffolds. The results showed that co-culture of smooth muscle cells (SMCs) and endothelial cells (ECs) using a collagen-PLGA scaffold under a pulsating perfusion system enhanced the development of vascular EC and preserved the differentiated cell phenotype (40).

Due to the good biocompatibility of fish collagen, the researchers use extra methylation modification and 1, 4butanediol diglycidyl ether (BDE) crosslinking steps to improve the scales of the collagen derived from the physical and chemical properties. It was found that collagen integration plaques with the surrounding tissue was good. The infiltration of cells, blood vessels and lymphatic vessels was good. This study demonstrates the collagen derived from fish scales as a promising scaffold material in various biomedical applications (67).

\section{Spinal Cord Injury Repair and Nerve Regeneration}

MDC has also been used in spinal cord regeneration. A new double-layer collagen membrane was designed and tested in a rat model of incomplete spinal cord injury. The previous research results showed that the transplantation of neural stem cells into a double-layer collagen membrane with different pore size promoted the differentiation of neural stem cells, alleviated the pathological injury, and improved the motor function of rats with incomplete spinal cord injury significantly (121).

Tilapia skin collagen was obtained by acid solution method and the stiffness of brain tissue was replicated for in vitro recombination experiments. By adding a cross-linker, a gel with a hardness similar to that of living brain tissue $(150-1,500 \mathrm{~Pa})$ was obtained, and the ability of the gel as a stem cell medium and the effect of hardness on neural lineage differentiation using human Induced pluripotent stem (iPS) cells were further investigated. It was found that exposure to a gel with a hardness of about 1,500 $\mathrm{Pa}$ promoted the production of neurons in the dorsal cortex during the early stages of neuroinduction (37).

To study the neuroprotective effects of MDC peptides (MCPs) isolated from salmon skin by enzymatic hydrolysis on perinatal asphyxia in male rats. Researchers found that MCPS promoted long-term learning and memory in perinatal asphyxia (PA) pups by decreasing oxidative damage and acetylcholinesterase (AChE) activity in the brain, and increasing the expression of p-CREB and brain-derived neurotrophic factor (BDNF) in the hippocampus (53).

\section{Skin Tissue Engineering and Wound Healing}

MDC has significant biological activity and plays an important role in skin tissue. MDC can promote wound healing. For example, the study used the MDC peptide (MCP) in Nile tilapia skin to carry out the burn wound experiment in deep part thickness of rabbits and the scratch experiment in vitro of rats (14). At the same time, there is also a research team, for example, using porous collagen sponge to conduct experiments on burned wounds in rats (114), using jellyfish collagen polypeptide to conduct oral experiments in rats and salmon skin wounds in rats (54), using ethylene amine and fish scale collagen to conduct 
wound experiments in rats (113), all of which indicate that MCP can promote wound healing. Moreover, its suitability as a dermal substitute was found in the wound healing experiment of rat model (78). The researchers found that MDC could quickly and effectively promote the wound healing of rats (26). If it is made into scaffolds or nanofibers, it can also promote wound healing. The researchers prepared chitosan/sponge collagen/glycerin three-dimensional porous scaffolds and bionic electrospinning fish collagen/bioactive glass (COL/BG) nanofibers. The healing experiments on rat skin wounds also showed the ability of MDC to promote wound healing $(35,36)$. At the same time, MDC is also an excellent scaffold for skin tissue regeneration (79), and a potential wound dressing with antimicrobial properties (115).

In vivo experiments with MDC scaffolds from Cadfish and Weever showed that the scaffolds promoted the proliferation and migration of $\mathrm{NIH} / 3 \mathrm{~T} 3$ fibroblasts, and promoted tissue regeneration and healing $(111,124)$. Fibroblasts from small hamster kidney (BHK21) were inoculated on a three-dimensional collagen gel. The results showed that it could activate the proliferation of BHK-21 cells, so MDC could be used as a potential biomaterial extract for biomedical applications (112).

Hydrolyzed collagen is a kind of more and more popular health care products, its molecular weight is very low peptide, easy to be digested, absorbed and distributed by human body. Many clinical trials have been completed and current studies have shown the effects and benefits of collagen peptides on skin, such as hydration, elasticity and reduction of wrinkles. Therefore, hydrolyzed collagen can be considered an important weapon in the world every day in the fight against skin aging (116). Some researchers used hydrolyzed MDC to conduct experiments on the cheek skin of women aged 45-60 years old, and found that it could reduce skin wrinkles, enhance elasticity and tightness, improve gloss, and effectively improve the skin health (110). Orthosilicic acid, which hydrolyzes collagen and stabilizes it, which also has this effect (117).

MDC plays an important role in skin wound healing. Researchers used Nile tilapia skin collagen extract to promote skin wound healing in rats, and the experimental group showed obvious signs of skin healing. Moreover, the expression levels of vascular endothelial growth factor (VEGF) and transforming growth factor- $\beta 1$ (TGF- $\beta 1$ ) were significantly increased, and the gene expressions of VEGF, basic fibroblast growth factor (bFGF) and Alpha-smooth muscle actin ( $\alpha$-SMA) were significantly upregulated. These results indicate that local application of Nile tilapia collagen extract can promote skin wound healing in rats, which may be due to its stimulating effect on the recruitment and activation of macrophages to produce chemotactic growth factors, fibroblast proliferation and angiogenesis (24). The researchers also used Snakehead fish collagen, Queen Fish skin collagen, Rhizostoma pulmo jellyfish collagen, and Giant Croaker (Nibea japonica) swim Bladders Collagen Japan swim bladder was used for wound healing experiment. Results show that the snakehead ossein paste made of white male rats sewer rat wound healing the best dose of $3 \%$ concentration (68), preparation of fish skin collagen hydrogel promote epithelial regeneration, and no water gel processing rat inflammatory cells angiogenesis, collagen deposition and hexose amine content, epithelium and wound contraction increased significantly (119). At the same time, Jellyfish collagen promotes artificial wound formation on the monolayer of human umbilical vein endothelial cells (HUVECs) (44). Japanese loach swim bladder Acid-soluble collagen (ASC) and pepsin soluble collagen (PSC) have good application in wound healing of mouse in vitro scratches (72). The researchers also found that oligopeptide compounds derived from marine fish peptides (MFPs) have the potential to significantly increase uterine scar tension, reduce the risk of uterine rupture, and promote uterine wound healing in rats following cesarean section (CS). It is speculated that its promoting effect may be related to the formation of new capillaries in scar tissue, the growth and repair of collagen fiber and smooth muscle tissue (118).

\section{Oral Mucosa Regeneration}

$\mathrm{MDC}$ also plays a role in the repair of oral mucosa. Researchers prepared chitosan-collagen composite scaffolds (C3) to construct oral mucosal equivalents (EVPOME-C) in vitro, and compared EVPOME-C with oral mucosal equivalents (EVPOME-B) and natural oral mucosa constructed with Alloderm ${ }^{\circledR}$ (EVPOMEA) and Biomend ${ }^{\mathrm{R}}$. The results showed that the C3 scaffold has a well-developed fiber network and a small enough porosity to prevent keratinocytes from growing in the scaffold after cell inoculation. The C3 scaffold has potential application value in epithelial tissue engineering, and provides a new treatment method for oral mucosal regeneration medicine (33).

\section{Corneal Tissue Engineering}

MDC has also been used in corneal tissue, in which fish scale-derived collagen matrix (FSCM) has been proposed as a substitute for human donor corneal tissue. To assess its biocompatibility, the FSCM was implanted as an anterior lamellar keratoplasty (ALK), placed in the interlamellar pouch (IL) and placed in the subconjunctiva (SC). The light transmittance was found to be similar to that through the human cornea. Implanting FSCM as an ALK resulted in only mild blurring, not pupil blurring, despite the presence of new blood vessels around the sutures; Interleukin placement causes moderate haze, partial occlusion of the pupil, and (partial) anterior lamella melting. The SC group showed local swelling and sclerosis, which decreased over time. Histology showed mild to moderate chronic inflammation in the ALK and IL groups, while severe inflammation was found in the SC group. Despite the technical difficulties, treatment of ALK with FSCM is feasible, while IL placement can cause anterior lamina melt. Further studies are needed to better understand its immunogenicity. The light scattering and transmission data suggest that the first version of the FSCM is comparable to human corneal tissue in this respect (32).

\section{IN DRUG DELIVERY SYSTEM}

MDC plays an important role in the drug delivery system, as shown in Table 5. For example, the researchers report a simple method of preparing collagenous peptide-chelated calcium (CPCC) from marine fish scales and a novel CPCCloaded nanoparticle to supplement calcium. Their experiments 
TABLE 5 | Applications of MDC in drug delivery system.

\begin{tabular}{|c|c|c|c|c|}
\hline Loaded drugs & Forms & Additive materials & Biological evaluation model & References \\
\hline Antibiotic (ampicillin and tetracycline) & Powder and film & / & / & $(64)$ \\
\hline Lysozyme & Microparticles & / & / & $(46)$ \\
\hline Growth factor (bFGF) & Scaffolds & Chitosan/chondroitin sulfate/PLGA & Rat full-thickness skin wound model & $(82)$ \\
\hline Ion (Calcium) & Nanoparticle & Calcium alginate & Rats' femur & (83) \\
\hline Ion (Calcium) & Injectable gel & Chitosan & Rats & $(60)$ \\
\hline$\alpha$-lactalbumin & Microparticles & / & / & $(46)$ \\
\hline Estrogen (17-beta-estradiol-hemihydrate) & Nanoparticle & / & Postmenopausal women & $(27)$ \\
\hline Gastroresistant tablets & Enteric coating & / & & (65) \\
\hline
\end{tabular}

showed that core-shell CPCC significantly increased bone mineral density and calcium content in the femur of rats, so the CPCC and core-shell CPCC nanoparticles are ideal choices for calcium supplementation (46). Acid-soluble collagen (ASC) and pepsin soluble collagen (PSC) isolated and identified from the waste skin of sea eel (Evenchely smacrura) can also be used for in vitro drug release experiments (83). The naturally keratinized sponges (Porous fungi, Dictyoceratida) are high in glycosaminoglycan content. It can be administered topically as a bio-based dressing and a biological active bionic carrier to regulate the process of wound healing (84). There are also spongy renal cartilages. A water-based gastric acid resistant coating dispersion was developed using renal sponge collagen $15 \%(\mathrm{~W} / \mathrm{W})$ as film forming agent. The results showed that the sponge collagen was resistant to drug for more than $2 \mathrm{~h}$ under the action of $0.1 \mathrm{M}$ hydrochloric acid and disintegrated within $10 \mathrm{~min}$ in the phosphate buffer solution of $\mathrm{pH}$ 6.8. The coated tablets had good mechanical properties and could be stored for more than 6 months without loss of intestinal solubility (60). In hormone replacement therapy, transdermal administration of estradiol bypasses the liver system before metabolism, and therefore has better side effects than oral estrogen. Renal cartilage sponge collagen nanoparticles were used as an osmotic accelerator for transdermal delivery of $17 \beta$-estradiol-hemihydrate for hormone replacement therapy. The results showed that the hydrogels containing estradiol collagen nanoparticles could prolong the release time of estradiol and significantly improve the absorption of estradiol. Therefore, sponge collagen nanoparticles are a promising carrier for transdermal drug delivery (64).

The researchers mixed MDC with other biomaterials. The chitosan and chum salmon skin MDC composite gel materials. The compound gel was injected subcutaneously into the back of rats. The specimens were collected for histological examination and ELISA to detect tumor necrosis factor $\alpha$ (TNF- $\alpha)$. It was found that the composite gel could be used as a carrier of tissue filler and drug delivery system (65).

MDC also has potential as a microprotein delivery system. The microgranular protein delivery system was developed using collagen extracted from the jellyfish Catostylus tagi as a polymer matrix. The researchers extracted collagen microparticles by emulsification-gel-solvent, and the CMPs collagen microparticles was cross-linked with 1-ethyl-3-(3-dimethylaminopropyl) carbon diimine (EDC). In vitro experiments showed that cross-linking also resulted in greater stability of CMP in water, allowing for slow release of microgranular proteins. These show the potential use of MDC in the production of microparticles for the controlled release of therapeutic proteins (27).

\section{IN COSMETICS AND SKINCARE}

MDC is a good moisturizer candidate, which has a wide range of functions in cosmetics. The researchers used MDC from the skin of salmon and cod as an ingredient in cosmetic formulas. Then the experimental results showed that collagen exhibited good water retention ability. Therefore, it is suitable as a moisturizer for skin application. Molecular markers of irritation and inflammation were analyzed that local exposure to collagen in the reconstructed human dermis was found to have no stimulating potential (85). The researchers also isolated collagen from grouper swim bladders and turned it into nanoscale collagen. To determine whether the chemical composition of collagen meets the quality standards of cosmetic raw materials, they did a lot of experiments. Finally, they found it have met the quality requirements of collagen standards as a cosmetic material based on Standar Nasional Indonesia (SNI) (87).

\section{IN FOODS AND HEALTH PRODUCTS}

MDC is also widely used in the field of food science and health products (Table 6). Currently, MDC or other-sourced collagen can be used as an emulsion to modify food, such as fish oil. Fish oil is rich in omega-3 unsaturated fatty acids and has many important physiological functions and potential for disease prevention. However, there are many disadvantages about it, such as its double bonds are too unstable to rupture, its fishy taste, and poor water solubility. These limit the application. There is a need to develop new formulations, food-emulsions are a practical method, to encapsulate fish oils for protection, increase water solubility and isolate the fishy smell.

There are many influence factors in the use of food-emulsions. To improve the emulsion's stability, researchers need to keep our eyes on the temperature, $\mathrm{pH}$, surface modification, storage time and so on. Emulsion stability mainly depends on droplet size and shell thickness (134). Higher storage temperatures (4$37^{\circ} \mathrm{C}$ ) cause the fish oil emulsion to change from a liquid 
TABLE 6 | Applications of MDC in foods and health care products.

\begin{tabular}{|c|c|c|c|}
\hline Applications & Forms & Functions & References \\
\hline \multirow[t]{4}{*}{ Emulsion } & Gelatin & Emulsion in food industry. & $(125)$ \\
\hline & Gelatin & Fish oil-loaded gelatin-stabilized emulsions in food. & $(126)$ \\
\hline & Gelatin & Optimal emulsion storage and transportation conditions in food. & $(127)$ \\
\hline & Gelatin and peptides & Decrease the creaming stability & $(128)$ \\
\hline Gelation & Peptides & Gelatins can increase the droplet stability and effect on the phase transition. & $(129)$ \\
\hline \multirow[t]{3}{*}{ Antioxidant } & Peptides & $\begin{array}{l}\text { GPEGPMGLE, EGPFGPEG, and GFIGPTE, might serve as potential antioxidants applied in } \\
\text { nutraceutical and pharmaceutical products. }\end{array}$ & $(130)$ \\
\hline & Gelatin & Antioxidative MCPs may increase life span and protection against tumor development. & $(131)$ \\
\hline & Peptides & Peptides serve as natural antioxidants in food and cosmetics. & $(132)$ \\
\hline Soft capsules & Gelatin & Electrospun nanofibers of MDC transport fish oi or nutrients to the stomach and intestines. & (133) \\
\hline
\end{tabular}

form to a redispersible gel form. It shows that increased temperatures decreased the creaming stability differences (128). The $\mathrm{pH}$ of gelatin solution, the speed of homogenizer and the homogenizing time also have important effects on the stability of the emulsion. The gelatin solution $\mathrm{pH}$, speed of homogenizer and the homogenizing time also have important effects on the stability of droplet sizes linearly decreased with increased of solution $\mathrm{pH}$ and homogenizing times. Droplet sizes exponentially decreased with increased of homogenizing speeds (135). There are results demonstrating that Cooperative adsorption has better emulsion stability than competitive adsorption. In the work, they mainly explored the gelatin is combined with four surfactants [soybean lecithin (SL), sodium dodecyl sulfate (SDS), Span 80 and Tween 80], which adsorb each other at the oil-water interface, which can improve or decrease the stability of the emulsion (136). These results are connected with the changes of $\mathrm{pH}$, too. The stability results of gelatin/surfactant co-stabilized (Span 80 and SL) or competitive stabilized (Tween 80 and SDS) were studied under different $\mathrm{pH}$ backgrounds (137).

Gelations can be modified by different surface modifications. Bovine and fish gelatins were modified by octenyl succinic anhydride (OSA) (125). The DS increase of OSA-modified bovine bone gelatins increases the droplet stability, but the DS increase of OSA-modified fish skin gelatins can only increases of the droplet stability and effects on the phase transition and creaming index of fish oil-loaded emulsions is very weak. The new formulation of oat $\beta$-glucan (OG)-MDC peptide mixed gels was researched. It has guiding significance for the formulation of low-fat meat products and is beneficial to improve food safety and nutritional value (129).

Collagen peptides may be used as a potential antioxidant in nutritional and pharmaceutical products. Prious research has shown that collagen peptides can serve as natural antioxidants in a variety of applications, such as food and cosmetics (138). Antioxidant Peptides from Gelatin Hydrolysate of Skipjack Tuna (Katsuwonus pelamis) might serve as potential antioxidants applied in health food industries (130). Antioxidant peptides from collagen hydrolysate showed that collagen peptides might serve as potential antioxidants applied in nutraceutical and pharmaceutical products (131). Previous studies have shown that MDC-prepared skin has two effects, namely extending the life span of rats and inhibiting the spontaneous occurrence of tumors. This result indirectly proves that the antioxidant properties of MCPs may be the cause, regarding the extension of life and protection of tumor development (132).

\section{CONCLUSION AND OUTLOOK}

Marine-derived collagen (MDC) has good biocompatibility and biodegradability. In recent years, scientists have made extensive exploration in food emulsions and biomedical applications. MDC can be extracted from fish waste products, which is an economical and sustainable source of collagen and can be used as an alternative to land-based collagen. Land-based collagen carries the risk of transmission of zoonotic diseases such as bovine sponge encephalopathy and hand, foot and mouth disease. For religious reasons, pig-derived collagen cannot be used in some foods. MDC protein has a very important application in food. MDC can be used as a food emulsion to encapsulate fish oil for protection. It has guiding significance for the formulation of lowfat meat products and is beneficial to improve food safety and nutritional value. In nutraceutical and pharmaceutical products, MDC might serve as potential antioxidants, even can inhibit the development of tumors.

Similar to materials such as polyhydroxyalkanoate (PHA) (139), PLGA (140), MDC is widely used in medical tissue, especially in bone tissue engineering, cartilage tissue engineering and functional repair of skin tissue. Good biocompatibility makes it the best template for cell growth. At the same time, scaffolds made of MDC can enable cells to live in 3D space $(141,142)$, thus improving the efficiency of culture, and collagen can induce cell differentiation in some specific environments, so as to produce specific functions. In addition, due to its biodegradability, MDC can be a good drug encapsulation and sustained-release system $(141,143)$ to improve the effectiveness of drug delivery. Of course, MDC also has some drawbacks. MDC is not strong enough, which makes its scaffold mechanical properties inadequate. In 2015, tilapia was proved to have good biocompatibility and can effectively induce skin regeneration (25). In order to explore the potential clinical application value of gill dolphin collagen materials, gill dolphin collagen extracted from gill dolphin skin was compared with tilapia collagen (144). 
The gill dolphin collagen and tilapia collagen were dissolved in $0.5 \mathrm{~mol} / \mathrm{L}$ acetic acid to form the membrane by casting method. The morphological structure, aqueous solubility and mechanical properties of gill dolphin and tilapia collagen membranes were characterized. The degradability and biocompatibility of the two materials were tested by subcutaneous implantation and cell culture $(145,146)$. The samples were detected at the experimentally specified time, and the application potential of the gill dolphin collagen membrane was evaluated by contrast with the tilapia collagen membrane. However, MDC also has the characteristics of low mechanical strength and rapid degradation in vivo, which can be solved by crosslinking with other natural or synthetic polymers. Therefore, $25 \%$ glutaraldehyde crosslinking can improve the mechanical strength and degradation characteristics of collagen membrane $(147,148)$. The residual glutaraldehyde after crosslinking was treated with glycine (149).

Based on this review, there are not many kinds of MDC available in the market at present, but there are abundant kinds of marine organisms with excellent physical and chemical properties. Therefore, the application prospect of all kinds of

\section{REFERENCES}

1. Silvipriya K, Kumar K, Bhat A, Kumar B, John A, Lakshmanan P. Collagen: animal sources and biomedical application. J Appl Pharm Sci. (2015) 5:12327. doi: 10.7324/japs.2015.50322

2. Lim YS, Ok YJ, Hwang SY, Kwak JY, Yoon S. Marine collagen as a promising biomaterial for biomedical applications. Mar Drugs. (2019) 17:80467.do i: $10.3390 / \mathrm{md} 17080467$

3. Parenteau-Bareil R, Gauvin R, Berthod F. Collagen-based biomaterials for tissue engineering applications. Materials. (2010) 3:1863. doi: 10.3390/ma3031863

4. Abou Neel EA, Bozec L, Knowles JC, Syed O, Mudera V, Day R, et al. Collagen - emerging collagen based therapies hit the patient. Adv Drug Deliv Rev. (2013) 65:429-56. doi: 10.1016/j.addr.2012.08.010

5. Colchester ACF, Colchester NTH. The origin of bovine spongiform encephalopathy: the human prion disease hypothesis. Lancet. (2005) 366:856-61. doi: 10.1016/S0140-6736(05)67218-2

6. Jin S, Sun F, Zou Q, Huang J, Zuo Y, Li Y, et al. Fish collagen and hydroxyapatite reinforced poly(lactide-co-glycolide) fibrous membrane for guided bone regeneration. Biomacromolecules. (2019) 20:2058-67. doi: 10.1021/acs.biomac.9b00267

7. Ferreira AM, Gentile P, Chiono V, Ciardelli G. Collagen for bone tissue regeneration. Acta Biomater. (2012) 8:3191200. doi: 10.1016/j.actbio.2012.06.014

8. Yamada S, Yamamoto K, Ikeda T, Yanagiguchi K, Hayashi Y. Potency of fish collagen as a scaffold for regenerative medicine. Biomed Res Int. (2014) 2014:302932. doi: 10.1155/2014/302932

9. Yamamoto K, Igawa K, Sugimoto K, Yoshizawa Y, Yanagiguchi K, Ikeda T, et al. Biological safety of fish (tilapia) collagen. Biomed Res Int. (2014) 2014:630757. doi: 10.1155/2014/630757

10. Leary D, Vierros M, Hamon G, Arico S, Monagle C. Marine genetic resources: A review of scientific and commercial interest. Mar Policy. (2009) 33:18394. doi: 10.1016/j.marpol.2008.05.010

11. Singh P, Benjakul S, Maqsood S, Kishimura $H$. Isolation and characterization of collagen extracted from the skin of striped catfish (Pangasianodon hypophthalmus). Food Chem. (2011) 124:97-105. doi: 10.1016/j.foodchem.2010.05.111

12. Muralidharan N, Jeya Shakila R, Sukumar D, Jeyasekaran G. Skin, bone and muscle collagen extraction from the trash fish, leather jacket (Odonus niger) and their characterization. J Food Sci Technol. (2013) 50:110613. doi: $10.1007 / \mathrm{s} 13197-011-0440-\mathrm{y}$
MDC is broad. As a new type of biomaterial, MDC egg has been widely recognized and attracted more and more attention from researchers in clinical, medicine, food and other fields.

\section{AUTHOR CONTRIBUTIONS}

NX, X-LP, and H-RL reviewed the literature and wrote this manuscript. J-XL and J-S-YC collected the data and critically reviewed this manuscript. X-YQ and S-JY reviewed the literature and wrote this manuscript. H-LG and X-HZ read and approved the final manuscript. JY and GX designed this manuscript. D-XW designed, reviewed the literature, and wrote this manuscript. All authors read and approved the final manuscript.

\section{FUNDING}

This work was supported by Grants from National Natural Science Foundation of China (Grant No. 31900950) and Project supported by the Natural Science Foundation of Shanghai, China (Grant No. 20ZR1469800).

13. Wang L, An X, Xin Z, Zhao L, Hu Q. Isolation and characterization of collagen from the skin of deep-sea redfish (sebastes mentella). J Food Sci. (2007) 72:E450-55. doi: 10.1111/j.1750-3841.2007.00478.x

14. Hu Z, Yang P, Zhou C, Li S, Hong P. Marine collagen peptides from the skin of Nile Tilapia (Oreochromis niloticus): characterization and wound healing evaluation. Marine Drugs. (2017) 15:40102. doi: 10.3390/md150 40102

15. Carvalho DN, López-Cebral R, Sousa RO, Alves AL, Reys LL, Silva SS, et al. Marine collagen-chitosan-fucoidan cryogels as cell-laden biocomposites envisaging tissue engineering. Biomed Mater. (2020) 15:055030. doi: 10.1088/1748-605x/ab9f04

16. Tziveleka LA, Ioannou E, Tsiourvas D, Berillis P, Foufa E, Roussis V. Collagen from the marine sponges axinella cannabina and suberites carnosus: isolation and morphological, biochemical, and biophysical characterization. Mar Drugs. (2017) 15:60152. doi: 10.3390/md15060152

17. Rodríguez F, Morán L, González G, Troncoso E, Zúñiga RN. Collagen extraction from mussel byssus: a new marine collagen source with physicochemical properties of industrial interest. J Food Sci Technol. (2017) 54:1228-38. doi: 10.1007/s13197-017-2566-z

18. Hörner C, Schürmann C, Auste A, Ebenig A, Muraleedharan S, Dinnon $\mathrm{KH}$, et al. A highly immunogenic and effective measles virusbased Th1-biased COVID-19 vaccine. Proc Natl Acad Sci USA. (2020) 117:32657. doi: 10.1073/pnas.2014468117

19. Akita M, Nishikawa Y, Shigenobu Y, Ambe D, Morita T, Morioka K, et al. Correlation of proline, hydroxyproline and serine content, denaturation temperature and circular dichroism analysis of type I collagen with the physiological temperature of marine teleosts. Food Chem. (2020) 329:126775. doi: 10.1016/j.foodchem.2020.126775

20. Carvalho AM, Marques AP, Silva TH, Reis RL. Evaluation of the potential of collagen from codfish skin as a biomaterial for biomedical applications. Marine Drugs. (2018) 16:495. doi: 10.3390/md16120495

21. Zhu L, Li J, Wang Y, Sun X, Li B, Poungchawanwong S, et al. Structural feature and self-assembly properties of type II collagens from the cartilages of skate and sturgeon. Food Chem. (2020) 331:127340. doi: 10.1016/j.foodchem.2020.127340

22. Qiu YT, Wang YM, Yang XR, Zhao YQ, Chi CF, Wang B. Gelatin and antioxidant peptides from gelatin hydrolysate of skipjack tuna (katsuwonus pelamis) scales: preparation, identification and activity evaluation. Marine Drugs. (2019) 17:565. doi: 10.3390/md17100565

23. Wu J, Guo X, Liu H, Chen L. Isolation and comparative study on the characterization of guanidine hydrochloride soluble collagen and pepsin 
soluble collagen from the body of surf clam shell (Coelomactra antiquata). Foods. (2019) 8:10011. doi: 10.3390/foods8010011

24. Elbialy ZI, Atiba A, Abdelnaby A, Al-Hawary II, Elsheshtawy A, ElSerehy HA, et al. Collagen extract obtained from Nile tilapia (Oreochromis niloticus L.) skin accelerates wound healing in rat model via up regulating VEGF, bFGF, and $\alpha$-SMA genes expression. BMC Vet Res. (2020) 16:352. doi: 10.1186/s12917-020-02566-2

25. Song WK, Liu D, Sun LL, Li BF, Hou H. Physicochemical and biocompatibility properties of type I collagen from the skin of Nile Tilapia (Oreochromis niloticus) for biomedical applications. Mar Drugs. (2019) 17:137. doi: $10.3390 / \mathrm{md} 17030137$

26. Chen J, Gao K, Liu S, Wang S, Elango J, Bao B, et al. Fish collagen surgical compress repairing characteristics on wound healing process in vivo. Mar Drugs. (2019) 17:33. doi: 10.3390/md17010033

27. Nicklas M, Schatton W, Heinemann S, Hanke T, Kreuter J. Preparation and characterization of marine sponge collagen nanoparticles and employment for the transdermal delivery of $17 \beta$-estradiol-hemihydrate. Drug Dev Industr Pharm. (2009) 35:1035-42. doi: 10.1080/03639040902755213

28. Liu C, Sun J. Potential application of hydrolyzed fish collagen for inducing the multidirectional differentiation of rat bone marrow mesenchymal stem cells. Biomacromolecules. (2014) 15:436-43. doi: 10.1021/bm40 $1780 \mathrm{v}$

29. Hsu HH, Uemura T, Yamaguchi I, Ikoma T, Tanaka J. Chondrogenic differentiation of human mesenchymal stem cells on fish scale collagen. $J$ Biosci Bioeng. (2016) 122:219-25. doi: 10.1016/j.jbiosc.2016.01.001

30. Tang J, Saito T. Biocompatibility of novel type I collagen purified from tilapia fish scale: an in vitro comparative study. BioMed Res Int. (2015) 2015:139476. doi: 10.1155/2015/139476

31. Liu C, Sun J. Hydrolyzed tilapia fish collagen induces osteogenic differentiation of human periodontal ligament cells. Biomed Mater. (2015) 10:065020. doi: 10.1088/1748-6041/10/6/065020

32. Van Essen TH, Lin CC, Hussain AK, Maas S, Lai HJ, Linnartz H, et al. A Fish scale-derived collagen matrix as artificial cornea in rats: properties and potential. Investig Ophthalmol Vis Sci. (2013) 54:322433. doi: $10.1167 /$ iovs.13-11799

33. Terada $M$, Izumi $K$, Ohnuki $H$, Saito $T$, Kato $H$, Yamamoto $M$, et al. Construction and characterization of a tissue-engineered oral mucosa equivalent based on a chitosan-fish scale collagen composite. J Biomed Mater Res Part B: Appl Biomater. (2012) 100B:1792-802. doi: 10.1002/jbm.b. 32746

34. Choi DJ, Choi SM, Kang HY, Min HJ, Lee R, Ikram M, et al. Bioactive fish collagen/polycaprolactone composite nanofibrous scaffolds fabricated by electrospinning for 3D cell culture. J Biotechnol. (2015) 205:4758. doi: 10.1016/j.jbiotec.2015.01.017

35. Ullah S, Zainol I, Chowdhury SR, Fauzi MB. Development of various composition multicomponent chitosan/fish collagen/glycerin 3D porous scaffolds: Effect on morphology, mechanical strength, biostability and cytocompatibility. Int J Biol Macromol. (2018) 111:158-68. doi: 10.1016/j.ijbiomac.2017.12.136

36. Zhou T, Sui B, Mo X, Sun J. Multifunctional and biomimetic fish collagen/bioactive glass nanofibers: fabrication, antibacterial activity and inducing skin regeneration in vitro and in vivo. Int J Nanomed. (2017) 12:3495-507. doi: 10.2147/IJN.S132459

37. Iwashita $M$, Ohta $H$, Fujisawa $T$, Cho $M$, Ikeya $M$, Kidoaki $S$, et al. Brain-stiffness-mimicking tilapia collagen gel promotes the induction of dorsal cortical neurons from human pluripotent stem cells. Sci Rep. (2019) 9:3068. doi: 10.1038/s41598-018-38395-5

38. Zhou T, Liu X, Sui B, Liu C, Mo X, Sun J. Development of fish collagen/bioactive glass/chitosan composite nanofibers as a GTR/GBR membrane for inducing periodontal tissue regeneration. Biomed Mater. (2017) 12:055004. doi: 10.1088/1748-605x/aa7b55

39. Tian Z, Mo X, Jiao S. Fabrication of electrospun tilapia collagen nanofibers and effect of promoting wound healing in vitro and in vivo. Front Bioeng Biotechnol. (2016) 4:1329. doi: 10.3389/conf.FBIOE.2016.01.01329

40. In Jeong S, Kim SY, Cho SK, Chong MS, Kim KS, Kim H, et al. Tissue-engineered vascular grafts composed of marine collagen and PLGA fibers using pulsatile perfusion bioreactors. Biomaterials. (2007) 28:111522. doi: 10.1016/j.biomaterials.2006.10.025
41. Bernhardt A, Paul B, Gelinsky M. Biphasic scaffolds from marine collagens for regeneration of osteochondral defects. Mar Drugs. (2018) 16:30091. doi: 10.3390/md16030091

42. Keller L, Keller L. Combined jellyfish collagen type II, human stem cells and Tgf- $\beta 3$ as a therapeutic implant for cartilage repair. J Stem Cell Res Therapy. (2017) 7:382. doi: 10.4172/2157-7633.1000382

43. Paradiso F, Fitzgerald J, Yao S, Barry F, Taraballi F, Gonzalez D, et al. Marine collagen substrates for 2D and 3D ovarian cancer cell systems. Front Bioeng Biotechnol. (2019) 7:343. doi: 10.3389/fbioe.2019.00343

44. Felician FF, Yu RH, Li MZ, Li CJ, Chen HQ, Jiang Y, et al. The wound healing potential of collagen peptides derived from the jellyfish Rhopilema esculentum. Chin J Traumatol. (2019) 22:12-20. doi: 10.1016/j.cjtee.2018.10.004

45. Bermueller C, Schwarz S, Elsaesser AF, Sewing J, Baur N, Von Bomhard A, et al. Marine collagen scaffolds for nasal cartilage repair: prevention of nasal septal perforations in a new orthotopic rat model using tissue engineering techniques. Tissue Eng Part A. (2013) 19:220114. doi: $10.1089 /$ ten.tea. 2012.0650

46. Calejo MT, Almeida AJ, Fernandes AI. Exploring a new jellyfish collagen in the production of microparticles for protein delivery. J Microencapsul. (2012) 29:520-31. doi: 10.3109/02652048.2012.665089

47. Pustlauk W, Paul B, Gelinsky M, Bernhardt A. Jellyfish collagen and alginate: Combined marine materials for superior chondrogenesis of hMSC. Mater Sci Eng: C. (2016) 64:190-98. doi: 10.1016/j.msec.2016.03.081

48. Diogo GS, López-Senra EL, Pirraco RP, Canadas RF, Fernandes EM, Serra J, et al. Marine collagen/apatite composite scaffolds envisaging hard tissue applications. Mar Drugs. (2018) 16:269. doi: 10.3390/md16080269

49. Elango J, Lee JW, Wang S, Henrotin Y, De Val JE, Regenstein J, et al. Evaluation of differentiated bone cells proliferation by blue shark skin collagen via biochemical for bone tissue engineering. Mar Drugs. (2018) 16:350. doi: $10.3390 / \mathrm{md} 16100350$

50. Hu CH, Yao CH, Chan TM, Huang TL, Sen Y, Huang CY, et al. Effects of different concentrations of collagenous peptide from fish scales on osteoblast proliferation and osteoclast resorption. Chin J Physiol. (2016) 59:191-201. doi: 10.4077/CJP.2016.BAE398

51. Sanchez A, Blanco M, Correa B, Perez-Martin RI, Sotelo CG. Effect of fish collagen hydrolysates on Type I collagen mRNA levels of human dermal fibroblast culture. Mar Drugs. (2018) 16:144. doi: 10.3390/md16050144

52. Pati F, Datta P, Adhikari B, Dhara S, Ghosh K, Mohapatra PKD. Collagen scaffolds derived from fresh water fish origin and their biocompatibility. $J$ Biomed Mater Res Part A. (2012) 100A:1068-79. doi: 10.1002/jbm.a.33280

53. Xu L, Dong W, Zhao J, Xu Y. Effect of marine collagen peptides on physiological and neurobehavioral development of male rats with perinatal asphyxia. Mar Drugs. (2015) 13:3653-71. doi: 10.3390/md13063653

54. Zhang Z, Wang J, Ding Y, Dai X, Li Y. Oral administration of marine collagen peptides from Chum Salmon skin enhances cutaneous wound healing and angiogenesis in rats. J Sci Food Agricult. (2011) 91:217379. doi: $10.1002 /$ jsfa. 4435

55. Zhu C, Zhang W, Mu B, Zhang F, Lai N, Zhou J, et al. Effects of marine collagen peptides on glucose metabolism and insulin resistance in type 2 diabetic rats. J Food Sci Technol. (2017) 54:2260-69. doi: 10.1007/s13197-017-2663-Z

56. Zhu CF, Li GZ, Peng HB, Zhang F, Chen Y, Li Y. Treatment with marine collagen peptides modulates glucose and lipid metabolism in Chinese patients with type 2 diabetes mellitus. Appl Physiol Nutr Metab. (2010) 35:797-804. doi: 10.1139/H10-075

57. Zhu CF, Li GZ, Peng HB, Li Y, Zhang F, Chen Y. Therapeutic effects of marine collagen peptides on chinese patients with type 2 diabetes mellitus and primary hypertension. Am J Med Sci. (2010) 340:36066. doi: 10.1097/MAJ.0b013e3181edfcf2

58. Zhu CF, Li GZ, Peng HB, Zhang F, Chen Y, Li Y. Effect of marine collagen peptides on markers of metabolic nuclear receptors in type 2 diabetic patients with/without hypertension. Biomed Environ Sci. (2010) 23:11320. doi: 10.1016/S0895-3988(10)60040-2

59. Yamada S, Nagaoka H, Terajima M, Tsuda N, Hayashi Y, Yamauchi M. Effects of fish collagen peptides on collagen post-translational modifications and mineralization in an osteoblastic cell culture system. Dental Mater J. (2013) 32:88-95. doi: 10.4012/dmj.2012-220 
60. Wang W, Itoh S, Aizawa T, Okawa A, Sakai K, Ohkuma T, et al. Development of an injectable chitosan/marine collagen composite gel. Biomed Mater. (2010) 5:065009. doi: 10.1088/1748-6041/5/6/065009

61. Velasco MA, Narváez-Tovar CA, Garzón-Alvarado DA. Design, materials, and mechanobiology of biodegradable scaffolds for bone tissue engineering. BioMed Res Int. (2015) 2015:729076. doi: 10.1155/2015/729076

62. Parisi JR, Fernandes KR, Avanzi IR, Dorileo BP, Santana AF, Andrade $\mathrm{AL}$, et al. Incorporation of collagen from marine sponges (Spongin) into hydroxyapatite samples: characterization and in vitro biological evaluation. Mar Biotechnol. (2019) 21:30-37. doi: 10.1007/s10126-018-9855-z

63. Pozzolini M, Millo E, Oliveri C, Mirata S, Salis A, Damonte G, et al. Elicited ROS scavenging activity, photoprotective, and wound-healing properties of collagen-derived peptides from the marine sponge chondrosia reniformis. Mar Drugs. (2018) 16:465. doi: 10.3390/md16120465

64. Langasco R, Cadeddu B, Formato M, Lepedda AJ, Cossu M, Giunchedi $\mathrm{P}$, et al. Natural collagenic skeleton of marine sponges in pharmaceutics: innovative biomaterial for topical drug delivery. Mater Sci Eng C. (2017) 70:710-20. doi: 10.1016/j.msec.2016.09.041

65. Nicklas M, Schatton W, Heinemann S, Hanke T, Kreuter J. Enteric coating derived from marine sponge collagen. Drug Dev Industr Pharm. (2009) 35:1384-88. doi: 10.3109/03639040902939239

66. Cruz MA, Fernandes KR, Parisi JR, Vale GCA, Junior SRA, Freitas FR, et al. Marine collagen scaffolds and photobiomodulation on bone healing process in a model of calvaria defects. J Bone Mineral Metab. (2020) 38:63947. doi: 10.1007/s00774-020-01102-4

67. Wang JK, Yeo KP, Chun YY, Tan TTY, Tan NS, Angeli V, et al. Fish scalederived collagen patch promotes growth of blood and lymphatic vessels in vivo. Acta Biomater. (2017) 63:246-60. doi: 10.1016/j.actbio.2017.09.001

68. Hasri NM, Zebua N, Sudewi. Test of burn wounds healing effects of collagen from snakehead fish (Channa striata) bone in the preparation of cream on male white rats (Rattus norvegicus). Indones J Pharm Clin Res. (2020) 3:62-75. doi: 10.32734/idjpcr.v3i1.3977

69. Lee EJ, Hur J, Ham SA, Jo Y, Lee S, Choi M-J, et al. Fish collagen peptide inhibits the adipogenic differentiation of preadipocytes and ameliorates obesity in high fat diet-fed mice. Int J Biol Macromol. (2017) 104:28186. doi: 10.1016/j.ijbiomac.2017.05.151

70. Ahmed R, Haq M, Chun B-S. Characterization of marine derived collagen extracted from the by-products of bigeye tuna (Thunnus obesus). Int J Biol Macromol. (2019) 135:668-76. doi: 10.1016/j.ijbiomac.2019.05.213

71. Diogo GS, Carneiro F, Freitas-Ribeiro S, Sotelo CG, Pérez-Martín RI, Pirraco $\mathrm{RP}$, et al. Prionace glauca skin collagen bioengineered constructs as a promising approach to trigger cartilage regeneration. Mater Sci Eng C. (2021) 120:111587. doi: 10.1016/j.msec.2020.111587

72. Chen Y, Jin H, Yang F, Jin S, Liu C, Zhang L, et al. Physicochemical, antioxidant properties of giant croaker (Nibea japonica) swim bladders collagen and wound healing evaluation. Int J Biol Macromol. (2019) 138:48391. doi: 10.1016/j.ijbiomac.2019.07.111

73. Arumugam GKS, Sharma D, Balakrishnan RM, Ettiyappan JBP. Extraction, optimization and characterization of collagen from sole fish skin. Sustain Chem Pharm. (2018) 9:19-26. doi: 10.1016/j.scp.2018.04.003

74. Yamada S, Yoshizawa Y, Kawakubo A, Ikeda T, Yanagiguchi K, Hayashi Y. Early gene and protein expression associated with osteoblast differentiation in response to fish collagen peptides powder. Dental Mater J. (2013) 32:23340. doi: $10.4012 / \mathrm{dmj} .2012-188$

75. Matsumoto R, Uemura T, Xu Z, Yamaguchi I, Ikoma T, Tanaka J. Rapid oriented fibril formation of fish scale collagen facilitates early osteoblastic differentiation of human mesenchymal stem cells. J Biomed Mater Res Part A. (2015) 103:2531-39. doi: 10.1002/jbm.a.35387

76. Mredha MTI, Kitamura N, Nonoyama T, Wada S, Goto K, Zhang X, et al. Anisotropic tough double network hydrogel from fish collagen and its spontaneous in vivo bonding to bone. Biomaterials. (2017) 132:8595. doi: 10.1016/j.biomaterials.2017.04.005

77. Ohnishi A, Osaki T, Matahira Y, Tsuka T, Imagawa T, Okamoto Y, et al. Evaluation of the chondroprotective effects of glucosamine and fish collagen peptide on a rabbit ACLT model using serum biomarkers. J Vet Med Sci. (2012) 75:421-9. doi: 10.1292/jvms.12-0240

78. Pal P, Srivas PK, Dadhich P, Das B, Maity PP, Moulik D, et al. Accelerating full thickness wound healing using collagen sponge of mrigal fish (Cirrhinus cirrhosus) scale origin. Int J Biol Macromol. (2016) 93:150718. doi: 10.1016/j.ijbiomac.2016.04.032

79. Chandika P, Ko SC, Oh GW, Heo SY, Nguyen VT, Jeon YJ, et al. Fish collagen/alginate/chitooligosaccharides integrated scaffold for skin tissue regeneration application. Int J Biol Macromol. (2015) 81:50413. doi: 10.1016/j.ijbiomac.2015.08.038

80. Nam JS, Sharma AR, Jagga S, Lee DH, Sharma G, Nguyen LT, et al. Suppression of osteogenic activity by regulation of WNT and BMP signaling during titanium particle induced osteolysis. J Biomed Mater Res Part A. (2017) 105:912-26. doi: 10.1002/jbm.a.36004

81. Krishnan S, Sekar S, Katheem MF, Krishnakumar S, Sastry TP. Fish scale collagen-a novel material for corneal tissue engineering. Artif Organs. (2012) 36:829-35. doi: 10.1111/j.1525-1594.2012.01452.x

82. Cao H, Chen MM, Liu Y, Liu YY, Huang YQ, Wang JH, et al. Fish collagenbased scaffold containing PLGA microspheres for controlled growth factor delivery in skin tissue engineering. Colloids Surfaces B: Biointerfaces. (2015) 136:1098-106. doi: 10.1016/j.colsurfb.2015.10.022

83. Guo H, Hong Z, Yi R. Core-shell collagen peptide chelated calcium/calcium alginate nanoparticles from fish scales for calcium supplementation. J Food Sci. (2015) 80:N1595-601. doi: 10.1111/1750-3841.12912

84. Veeruraj A, Arumugam M, Ajithkumar T, Balasubramanian T. Isolation and characterization of drug delivering potential of type-I collagen from eel fish Evenchelys macrura. J Mater Sci Mater Med. (2012) 23:1729_ 38. doi: 10.1007/s10856-012-4650-2

85. Alves AL, Marques ALP, Martins E, Silva TH, Reis RL. Cosmetic potential of marine fish skin collagen. Cosmetics. (2017) 4:39. doi: $10.3390 /$ cosmetics 4040039

86. Danila E, Stan R, Kaya MA, Voicu G, Marin MM, Moroşan A, et al. Valorization of Cyprinus Carpio skin for biocompatible collagen hydrolysates with potential application in foods, cosmetics and pharmaceuticals. Res Sq [preprint]. (2021). doi: 10.21203/rs.3.rs-227 096/v1

87. Trilaksani W, Adnyane IKM, Riyanto B, Safitri N. Nano collagen of the grouper swim bladder in compliance with quality standard of cosmetics materials. IOP Confer S: Earth Environ Sci. (2019) 404:012050. doi: 10.1088/1755-1315/404/1/012050

88. Khong NMH, Yusoff FM, Jamilah B, Basri M, Maznah I, Chan KW, et al. Improved collagen extraction from jellyfish (Acromitus hardenbergi) with increased physical-induced solubilization processes. Food Chemistry. (2018) 251:41-50. doi: 10.1016/j.foodchem.2017.12.083

89. Wichuda J, Sunthorn C, Busarakum P. Comparison of the properties of collagen extracted from dried jellyfish and dried squid. Afr J Biotechnol. (2016) 15:642-48. doi: 10.5897/ajb2016.15210

90. Gaurav Kumar P, Nidheesh T, Govindaraju K, Jyoti, Suresh PV. Enzymatic extraction and characterization of a thermostable collagen from swim bladder of rohu (Labeo rohita). J Sci Food Agric. (2017) 97:145158. doi: $10.1002 /$ jsfa.7884

91. Seixas MJ, Martins E, Reis RL, Silva TH. Extraction and characterization of collagen from elasmobranch byproducts for potential biomaterial use. Mar Drugs. (2020) 18:20617. doi: 10.3390/md18120617

92. Wu R, Chen L, Liu D, Huang J, Zhang J, Xiao X, et al. Preparation of antioxidant peptides from salmon byproducts with bacterial extracellular proteases. Marine Drugs. (2017) 15:4. doi: 10.3390/md15010004

93. Song Z, Liu H, Chen L, Chen L, Zhou C, Hong P, et al. Characterization and comparison of collagen extracted from the skin of the Nile tilapia by fermentation and chemical pretreatment. Food Chem. (2021) 340:128139. doi: 10.1016/j.foodchem.2020.128139

94. Elmowafy E, Abdal-Hay A, Skouras A, Tiboni M, Casettari L, Guarino V. Polyhydroxyalkanoate (PHA): applications in drug delivery and tissue engineering. Exp Rev Med Dev. (2019) 16:467-82. doi: 10.1080/17434440.2019.1615439

95. Chen J, Li M, Yi R, Bai K, Wang G, Tan R, et al. Electrodialysis extraction of pufferfish skin (Takifugu flavidus): a promising source of collagen. Marine Drugs. (2019) 17:10025. doi: 10.3390/md17010025

96. Sousa RO, Martins E, Carvalho DN, Alves AL, Oliveira C, Duarte ARC, et al. Collagen from Atlantic cod (Gadus morhua) skins extracted using CO2 acidified water with potential application in healthcare. J Polymer Res. (2020) 27:73. doi: 10.1007/s10965-020-02048-x 
97. Sousa RO, Alves AL, Carvalho DN, Martins E, Oliveira C, Silva TH, et al. Acid and enzymatic extraction of collagen from Atlantic cod (Gadus Morhua) swim bladders envisaging health-related applications. J Biomater Sci Polymer Edition. (2020) 31:20-37. doi: 10.1080/09205063.2019.1669313

98. Li PH, Lu WC, Chan YJ, Ko WC, Jung CC, Le Huynh DT, et al. Extraction and characterization of collagen from sea cucumber (Holothuria cinerascens) and its potential application in moisturizing cosmetics. Aquaculture. (2020) 515:734590. doi: 10.1016/j.aquaculture.2019.734590

99. Lin Z, Tao Y, Huang $\mathrm{Y}, \mathrm{Xu} \mathrm{T}$, Niu W. Applications of marine collagens in bone tissue engineering. Biomed Mater. (2021) 16:042007. doi: 10.1088/1748-605x/abf0b6

100. Pallela R, Venkatesan J, Bhatnagar I, Shim Y, Kim S. Applications of Marine Collagen-Based Scaffolds in Bone Tissue Engineering. Boca Raton, FL: CRC Press (2013). doi: 10.1201/b14723-30

101. Al-Ghaban N. Histomorphometric evaluation of the effect of local application of moringa oliefera/marine collagen on bone healing in rats. $J$ Res Med Dental Sci. (2021) 9:225-230.

102. Liu C, Sun J. Impact of marine-based biomaterials on the immunoregulatory properties of bone marrow-derived mesenchymal stem cells: potential use of fish collagen in bone tissue engineering. ACS Omega. (2020) 5:2836068. doi: 10.1021/acsomega.0c04360

103. Yang Y, Yue W, Zhang D, Sun H, Tong X, Fang H, et al. [Marine fish bone collagen oligopeptide combined with calcium aspartate increases bone mineral density in obariectomized rats]. Wei sheng yan jiu $=J$ Hygiene Res. (2019) 48:606-10.

104. Xu Y, Han X, Li Y. Effect of marine collagen peptides on long bone development in growing rats. J Sci Food Agricult. (2010) 90:148591. doi: 10.1002/jsfa.3972

105. Hoyer B, Bernhardt A, Lode A, Heinemann S, Sewing J, Klinger M, et al. Jellyfish collagen scaffolds for cartilage tissue engineering. Acta Biomater. (2014) 10:883-92. doi: 10.1016/j.actbio.2013.10.022

106. Li H, Chen R, Jia Z, Wang C, Xu Y, Li C, et al. Porous fish collagen for cartilage tissue engineering. Am J Translat Res. (2020) 12:6107-21.

107. Shaohua Z, Yigong W, Yong XU, Liang D. Fish collagen in constructing tissue-engineered cartilage. J Tissue Eng Reconst Surg. (2019) 15:379. doi: 10.3969/j.issn.1673-0364.2019.06.002

108. Raabe O, Reich C, Wenisch S, Hild A, Burg-Roderfeld M, Siebert HC, et al. Hydrolyzed fish collagen induced chondrogenic differentiation of equine adipose tissue-derived stromal cells. Histochem Cell Biol. (2010) 134:54554. doi: 10.1007/s00418-010-0760-4

109. Cheung RC, Ng TB, Wong JH. Marine peptides: bioactivities and applications. Mar Drugs. (2015) 13:4006. doi: 10.3390/md13074006

110. Evans M, Lewis ED, Zakaria N, Pelipyagina T, Guthrie N. A randomized, triple-blind, placebo-controlled, parallel study to evaluate the efficacy of a freshwater marine collagen on skin wrinkles and elasticity. $J$ Cosmetic Dermatol. (2021) 20:825-34. doi: 10.1111/jocd.13676

111. Zhang J, Sun Y, Zhao Y, Wei B, Xu C, He L, et al. Centrifugation-induced fibrous orientation in fish-sourced collagen matrices. Soft Matter. (2017) 13:9220-28. doi: 10.1039/C7SM01871A

112. El-Rashidy AA, Gad A, Abu-Hussein AE-HG, Habib SI, Badr NA, Hashem AA. Chemical and biological evaluation of Egyptian Nile Tilapia (Oreochromis niloticas) fish scale collagen. Int J Biol Macromol. (2015) 79:618-26. doi: 10.1016/j.ijbiomac.2015.05.019

113. Jana P, Mitra T, Selvaraj TKR, Gnanamani A, Kundu PP. Preparation of guar gum scaffold film grafted with ethylenediamine and fish scale collagen, cross-linked with ceftazidime for wound healing application. Carbohydr Polymers. (2016) 153:573-81. doi: 10.1016/j.carbpol.2016. 07.053

114. Muthukumar T, Prabu P, Ghosh K, Sastry TP. Fish scale collagen sponge incorporated with Macrotyloma uniflorum plant extract as a possible wound/burn dressing material. Colloids Surfaces B: Biointerfaces. (2014) 113:207-12. doi: 10.1016/j.colsurfb.2013.09.019

115. Wang Y, Zhang CL, Zhang Q, Li P. Composite electrospun nanomembranes of fish scale collagen peptides/chito-oligosaccharides: antibacterial properties and potential for wound dressing. Int J Nanomed. (2011) 6:66776. doi: $10.2147 /$ IJN.S17547

116. Sibilla S, Godfrey M, Brewer S, Budh-Raja A, Genovese L. An overview of the beneficial effects of hydrolysed collagen as a nutraceutical on skin properties: scientific background and clinical studies. Open Nutraceut J. (2015) 8:10029. doi: 10.2174/1876396001508010029

117. Petersen Vitello Kalil CL, Campos V, Cignachi S, Favaro Izidoro J, Prieto Herman Reinehr C, Chaves C. Evaluation of cutaneous rejuvenation associated with the use of ortho-silicic acid stabilized by hydrolyzed marine collagen. J Cosmetic Dermatol. (2018) 17:814-20. doi: 10.1111/jocd.12430

118. Peng X, Xu J, Tian Y, Liu W, Peng B. Marine fish peptides (collagen peptides) compound intake promotes wound healing in rats after cesarean section. Food Nutr Res. (2020) 64:4247. doi: 10.29219/fnr.v64.4247

119. Hema GS, Ganesan B, Shyni K, Joshy CG, Ninan G. Collagen hydrogel as bio interactive dressing for wound healing. Fishery Technol. (2017) 54:252-7. doi: 10.1016/s0142-9612(02)00100-x

120. Zhu C, Zhang W, Liu J, Mu B, Zhang F, Lai N, et al. Marine collagen peptides reduce endothelial cell injury in diabetic rats by inhibiting apoptosis and the expression of coupling factor 6 and microparticles. Mol Med Rep. (2017) 16:3947-57. doi: 10.3892/mmr.2017.7061

121. Yuan N, Tian W, Sun L, Yuan R, Tao J, Chen D. Neural stem cell transplantation in a double-layer collagen membrane with unequal pore sizes for spinal cord injury repair. Neural Regener. Res. (2014) 9:101419. doi: $10.4103 / 1673-5374.133160$

122. Sanz B, Albillos Sanchez A, Tangey B, Gilmore K, Yue Z, Liu X, et al. Light cross-linkable marine collagen for coaxial printing of a 3D model of neuromuscular junction formation. Biomedicines. (2021) 9:10016. doi: 10.3390/biomedicines9010016

123. Nurilmala M, Pertiwi RM, Nurhayati T, Fauzi S, Batubara I, Ochiai Y. Characterization of collagen and its hydrolysate from yellowfin tuna Thunnus albacares skin and their potencies as antioxidant and antiglycation agents. Fish Sci. (2019) 85:591-99. doi: 10.1007/s12562-019-01303-5

124. Li Q, Mu L, Zhang F, Sun Y, Chen Q, Xie C, et al. A novel fish collagen scaffold as dural substitute. Mater Sci Eng: C. (2017) 80:34651. doi: 10.1016/j.msec.2017.05.102

125. Zhang $\mathrm{T}$, Ding $\mathrm{M}$, Tao L, Liu L, Tao $\mathrm{N}$, Wang $\mathrm{X}$, et al. Octenyl succinic anhydride modification of bovine bone and fish skin gelatins and their application for fish oil-loaded emulsions. Food Hydrocolloids. (2020) 108:106041. doi: 10.1016/j.foodhyd.2020.106041

126. Zhang T, Sun R, Ding M, Tao L, Liu L, Tao N, et al. Effect of extraction methods on the structural characteristics, functional properties, and emulsion stabilization ability of Tilapia skin gelatins. Food Chem. (2020) 328:127114. doi: 10.1016/j.foodchem.2020.127114

127. Wang P, Ding M, Zhang T, Wu T, Qiao R, Zhang F, et al. Electrospraying technique and its recent application advances for biological macromolecule encapsulation of food bioactive substances. Food Rev Int. (2020) 123. doi: 10.1080/87559129.2020.1738455

128. Ding $\mathrm{M}$, Zhang T, Zhang H, Tao N, Wang X, Zhong J. Gelatin-stabilized traditional emulsions: Emulsion forms, droplets, and storage stability. Food Sci Hum Wellness. (2020) 9:320-27. doi: 10.1016/j.fshw.2020.04.007

129. Fan R, Zhou D, Cao X. Evaluation of oat $\beta$-glucan-marine collagen peptide mixed gel and its application as the fat replacer in the sausage products. PLoS ONE. (2020) 15:e0233447. doi: 10.1371/journal.pone.0233447

130. Yang XR, Zhao YQ, Qiu YT, Chi CF, Wang B. Preparation and characterization of gelatin and antioxidant peptides from gelatin hydrolysate of skipjack tuna (Katsuwonus pelamis) bone stimulated by in vitro gastrointestinal digestion. Mar Drugs. (2019) 17:78. doi: $10.3390 / \mathrm{md} 17020078$

131. Wang WY, Zhao YQ, Zhao GX, Chi CF, Wang B. Antioxidant peptides from collagen hydrolysate of redlip croaker (Pseudosciaena polyactis) scales: preparation, characterization, and cytoprotective effects on $\mathrm{H} 2 \mathrm{O} 2$-damaged HepG2 Cells. Mar Drugs. (2020) 18:156. doi: 10.3390/md18030156

132. Liang J, Pei XR, Wang N, Zhang ZF, Wang JB, Li Y. Marine collagen peptides prepared from chum salmon (Oncorhynchus keta) skin extend the life span and inhibit spontaneous tumor incidence in sprague-dawley rats. $\mathrm{J} \mathrm{Med}$ Food. (2010) 13:757-70. doi: 10.1089/jmf.2009.1279

133. Wang P, Li M, Wei D, Ding M, Tao L, Liu X, et al. Electrosprayed soft capsules of millimeter size for specifically delivering fish oil/nutrients to the stomach and intestines. ACS Appl Mater Interfaces. (2020) 12:653645. doi: 10.1021/acsami.9b23623

134. Zhang $\mathrm{T}$, Sun R, Ding M, Li L, Tao N, Wang X, et al. Commercial cold-water fish skin gelatin and bovine bone gelatin: Structural, 
functional, and emulsion stability differences. LWT. (2020) 125:109207. doi: 10.1016/j.lwt.2020.109207

135. Ding $\mathrm{M}$, Zhang $\mathrm{T}$, Zhang $\mathrm{H}$, Tao N, Wang X, Zhong J. Effect of preparation factors and storage temperature on fish oil-loaded crosslinked gelatin nanoparticle pickering emulsions in liquid forms. Food Hydrocolloids. (2019) 95:326-35. doi: 10.1016/j.foodhyd.2019.04.052

136. Zhang $\mathrm{T}$, Ding $\mathrm{M}$, Zhang $\mathrm{H}$, Tao N, Wang $\mathrm{X}$, Zhong J. Fish oilloaded emulsions stabilized by synergetic or competitive adsorption of gelatin and surfactants on oil/water interfaces. Food Chem. (2020) 308:125597. doi: 10.1016/j.foodchem.2019.125597

137. Zhang T, Ding M, Wang X, Zhong J. Droplet and creaming stability of fish oil-loaded gelatin/surfactant-stabilized emulsions depends on both the adsorption ways of emulsifiers and the adjusted pH. Food Sci Hum Wellness. (2020) 9:280-88. doi: 10.1016/j.fshw.2020.04.002

138. Shen Q, Ou A, Liu S, Elango J, Wang S, Henriques Da Silva T, et al. Effects of ion concentrations on the hydroxyl radical scavenging rate and reducing power of fish collagen peptides. J Food Biochem. (2019) 43:e12789. doi: 10.1111/jfbc.12789

139. Wei DX, Dao JW, Chen GQ. A micro-ark for cells: highly open porous polyhydroxyalkanoate microspheres as injectable scaffolds for tissue regeneration. Adv Mater. (2018) 30:1802273. doi: 10.1002/adma.201802273

140. Wei D, Qiao R, Dao J, Su J, Jiang C, Wang X, et al. Soybean lecithin-mediated nanoporous PLGA microspheres with highly entrapped and controlled released BMP-2 as a stem cell platform. Small. (2018) 14:1800063. doi: $10.1002 / \mathrm{smll} .201800063$

141. Zhao XH, Peng XL, Gong HL, Wei DX. Osteogenic differentiation system based on biopolymer nanoparticles for stem cells in simulated microgravity. Biomed Mater. (2021) 16:044102. doi: 10.1088/1748-605x/abe9d1

142. Wei DX, Dao JW, Liu HW, Chen GQ. Suspended polyhydroxyalkanoate microspheres as 3D carriers for mammalian cell growth. ArtifCells Nanomed Biotechnol. (2018) 46:473-83. doi: 10.1080/21691401.2018.1459635

143. Rahman M, Peng XL, Zhao XH, Gong HL, Sun XD, Wu Q, et al. 3D bioactive cell-free-scaffolds for in-vitro/in-vivo capture and directed osteoinduction of stem cells for bone tissue regeneration. Bioactive Mater. (2021) 6:408395. doi: 10.1016/j.bioactmat.2021.01.013

144. Iswariya S, Velswamy P, Uma TS. Isolation and characterization of biocompatible collagen from the skin of puffer fish (Lagocephalus inermis). J Poly Environ. (2018) 26:2086-95. doi: 10.1007/s10924-017-1107-1
145. Hassanbhai AM, Lau CS, Wen F, Jayaraman P, Goh BT, Yu N, et al. In vivo immune responses of cross-linked electrospun tilapia collagen membrane. Tissue Eng Part A. (2017) 23:1110-19. doi: 10.1089/ten.tea.20 16.0504

146. Mcpherson JM, Sawamura S, Armstrong R. An examination of the biologic response to injectable, glutaraldehyde cross-linked collagen implants. $J$ Biomed Mater Res. (1986) 20:93-107. doi: 10.1002/jbm.820200109

147. Veríssimo DM, Leitão RFC, Ribeiro RA, Figueiró SD, Sombra ASB, Góes JC, et al. Polyanionic collagen membranes for guided tissue regeneration: Effect of progressive glutaraldehyde crosslinking on biocompatibility and degradation. Acta Biomater. (2010) 6:4011-18. doi: 10.1016/j.actbio.2010.04.012

148. Tian Z, Li C, Duan L, Li G. Physicochemical properties of collagen solutions cross-linked by glutaraldehyde. Connect Tissue Res. (2014) 55:23947. doi: 10.3109/03008207.2014.898066

149. Marinucci L, Lilli C, Guerra M, Belcastro S, Becchetti E, Stabellini G, et al. Biocompatibility of collagen membranes crosslinked with glutaraldehyde or diphenylphosphoryl azide: An in vitro study. J Biomed Mater Res Part A. (2003) 67A:504-9. doi: 10.1002/jbm.a.10082

Conflict of Interest: The authors declare that the research was conducted in the absence of any commercial or financial relationships that could be construed as a potential conflict of interest.

Publisher's Note: All claims expressed in this article are solely those of the authors and do not necessarily represent those of their affiliated organizations, or those of the publisher, the editors and the reviewers. Any product that may be evaluated in this article, or claim that may be made by its manufacturer, is not guaranteed or endorsed by the publisher.

Copyright $\odot 2021$ Xu, Peng, Li, Liu, Cheng, Qi, Ye, Gong, Zhao, Yu, Xu and Wei. This is an open-access article distributed under the terms of the Creative Commons Attribution License (CC BY). The use, distribution or reproduction in other forums is permitted, provided the original author(s) and the copyright owner(s) are credited and that the original publication in this journal is cited, in accordance with accepted academic practice. No use, distribution or reproduction is permitted which does not comply with these terms. 